\title{
A mentális állapot populációs szintú vizsgálatának koncepciói és eszközei
}

\author{
KÓSA KAROLINA ${ }^{1 *}$ - BÍRÓ ÉVA² \\ ${ }^{1}$ Debreceni Egyetem, Népegészségügyi Kar, Magatartástudományi Intézet, Debrecen \\ ${ }^{2}$ Debreceni Egyetem, Népegészségügyi Kar, Megelőző Orvostani Intézet, Debrecen
}

(Beérkezett: 2017. október 24.; elfogadva: 2018. március 23.)

\begin{abstract}
Az elmúlt három évtizedben folyamatosan nőtt a nemzetközi érdeklődés a populációk mentális egészsége iránt, amit a témakörben nagy számban végzett tudományos kutatások és nemzetközi szakmai dokumentumok bizonyítanak. A téma iránti érdeklődéshez és elkötelezettséghez képest azonban a szakirodalomban igen alacsony a populációs adatokat szolgáltató, pontosan dokumentált, jól tervezett, és nemzetközi összehasonlításra is alkalmas vizsgálatok száma. Ez különösen igaz a hazai népesség mentális egészségével kapcsolatos kutatásokra, ami jelentős akadálya annak, hogy a mentális problémákkal küzdő hazai népesség különféle csoportjait célzottan segíteni képes, bizonyítékokon alapuló beavatkozásokat kínáló, több mint egy évtizede tervezett lelki egészség-stratégia elfogadásra kerüljön. E helyzet megoldásához kíván hozzájárulni a közlemény azáltal, hogy áttekintést ad a mentális állapot populációs mérésének konceptuális kérdéseiről, beleértve a mentális egészség átfogó témaköreit; valamint számba veszi a mentális zavarok, a generikus mentális állapot, és a mentális egészség, illetve a szubjektív jóllét vizsgálatára alkalmas, populációs vizsgálatokban leggyakrabban használt mérőeszközöket. A mentális egészség kérdéskörének jelentőségét és a magyar népesség mentális problémáira fókuszálva szükséges, a rendelkezésre álló széleskörú nemzetközi tapasztalatokat figyelembe véve pedig lehetséges a hazai népesség mentális állapotát az eddiginél átfogóbb, rendszeres, és nemzetközi összehasonlításra alkalmas eredményeket nyújtó módon vizsgálni, amely megalapozza a lelki egészség javítását hatékonyan szolgáló, bizonyítékokra alapozott országos stratégia megtervezését és eredményeinek nyomon követését.
\end{abstract}

Kulcsszavak: lelki egészség, epidemiológia, kérdőíves felmérés

\section{Bevezetés}

Az elmúlt három évtizedben egyre nőtt a nemzetközi érdeklődés a mentális egészség szerepe iránt, ezen belül is a populációk mentális egészsége iránt. Ezt tükrözte az Egészségügyi Világszervezet (World Health Organization; WHO) 2001-ben megjelent globális egészségriportja, amely teljes egészében

\footnotetext{
* Levelező szerző: Prof. Dr. Kósa Karolina, Debreceni Egyetem, Népegészségügyi Kar, Magatartástudományi Intézet, 4032 Debrecen, Móricz Zsigmond körút 22. E-mail: kosa.karolina@sph. unideb.hu
} 
e témakörról szólt (WHO, 2001). 2003-ban a WHO olyan anyagot tett közzé, amely a mentális egészségbe való beruházás szükségességét részletezte, amit a mentális zavarok ellátásának hiányosságai, az általuk okozott gazdasági terhek nagyságrendje, valamint a megelőzés széleskörú lehetőségei is indokolnak (WHO, 2003). E dokumentum 2013-ban megjelent folytatása már a bizonyítottan hatékony beavatkozásokra is kitért (WHO, 2013a), amit a mentális egészség javítására szolgáló, a 2013-2020 közti idószakra vonatkozó globális (WHO, 2013b) és európai (WHO, 2015a) cselekvési terv megalkotása követett. A lelki egészséggel kapcsolatos prioritásokat az Európai Unió (EU) 2008-ban határozta meg (depresszió és öngyilkosság megelőzése, fiatalok és idősek lelki egészsége, lelki egészség a munkahelyeken, valamint küzdelem a társadalmi kirekesztettség ellen) (Európai Bizottság, 2008); a WHO Európai Irodájával közösen elért haladásról 2016-ban számolt be (European Commission, 2016).

A WHO és az EU dokumentumaiban a mentális egészség témaköre iránt megnyilvánuló elkötelezettséghez képest a populációs adatokat szolgáltató, pontosan dokumentált és jól tervezett vizsgálatok száma igen csekély. Egy ausztrál kutatócsoport az 1980-2008 közti időszakot vizsgálva közel 77 ezer, mentális betegségekre vonatkozó epidemiológiai vizsgálatot azonosított, amelyeknek azonban mindössze 1 százaléka volt alkalmas arra, hogy nemzetközi összehasonlításra adatokat lehessen nyerni belőle. A legfőbb problémák között sorolták fel, hogy a vizsgálatok nem a nemzetközi standardok szerinti definíciót használták a betegségek azonosítására; nem volt reprezentatív a minta; nem jól választották meg a módszertant; és nem volt kellően részletes a módszertan ismertetése (Baxter, Patton, Scott, Degenhardt, \& Whiteford, 2013). Egy másik, a 2007-2012 közti időszakot európai szempontból áttekintő közlemény azt állapította meg, hogy a populációs vizsgálatok többsége a fejlett északi és nyugati országokban zajlik (Forsman, Ventus, van der Feltz-Cornelis, \& Wahlbeck, 2014).

A nemzetközi vizsgálatokkal kapcsolatos problémák csak részben vigasztalhatják a hazai szakembereket és szakpolitikai döntéshozókat, akik a mentális zavarokra, illetve a mentális állapotra vonatkozó részletes, reprezentatív, idősoros elemzésre is alkalmas, aktuálisnak tekinthető magyarországi adatok nélkül kénytelenek beavatkozásokat és döntéseket tervezni és kivitelezni, oktatni és kutatni. A felnőttkori mentális zavarok vonatkozásában a legutolsó epidemiológiai vizsgálatok Szádóczky Erika és munkatársai nevéhez fúződnek, mintegy két évtizeddel ezelőtt (Szádóczky, Fazekas, Füredi, \& Papp, 1996; Szádóczky, Rihmer, Papp, \& Füredi, 1997). Nem történt meg a populációs felmérésekre alkalmas legrészletesebb eszköz (CIDI kérdőív $)^{1}$ hazai adaptálása, amelynek következtében az ország nem tud be-

1 A tanulmányban említett kérdőívek teljes nevét és forrásait a 3-5. táblázatok részletezik. 
kapcsolódni az azt használó nagyszabású nemzetközi vizsgálatokba. A kutatói elkötelezettségen alapuló, rendszeres szakágazati támogatás nélkül zajló reprezentatív Hungarostudy vizsgálat a depresszió szempontjából veszélyeztetettek gyakoriságára vonatkozóan szolgáltat idősoros adatokat 1988-tól, de az abban használt rövidített, 9 tételes Beck szúrőskála eltér a nemzetközileg használatos, 13 tételes rövidített BDI skálától, és annak 7 tételes, az alapellátásban ajánlott változatától is, így az ezzel nyert adatok nemzetközi összehasonlításra csak korlátozottan alkalmasak. A vizsgálat utolsó három, illetve két adatfelvételének eszköztárában alkalmazásra kerültek olyan skálák (WBI-5, élettel való elégedettség, boldogság), amelyek - ha részei lesznek a további adatfelvételeknek - alkalmat nyújthatnak idősoros értelmezésre a lelki egészség vonatkozásában. Nemzetközi és idősoros összehasonlításra alkalmas adatok hiányában jelentős kihívást okoz bizonyítékokon alapuló lelki egészség-stratégiát alkotni.

A jelen közlemény a mentális állapot országos és országok közti, populációs mérésének elméleti és gyakorlati kérdéseinek áttekintésével, illetve a rendelkezésre álló mérőeszközök számba vételével kíván hozzájárulni a hazai népesség mentális egészségének javítását szolgáló kutatások tervezéséhez.

\section{A mentális állapot mérésének konceptuális kérdései}

\subsection{Mentális egészség vagy mentális betegség}

A mentális egészség és betegség szinonimaként való használata napjainkban is jellemző a szakterületre, annak ellenére, hogy a WHO alkotmánya már 1946-ban világosan utalt az egészség és betegség konceptuális különbözőségére (, az egészség meghatározása nem negatív vagy korlátozott mint a betegség hiánya, hanem pozitív és tág, úgymint a teljes testi, mentális és társas jólét") (WHO, 1946). Megjegyzendő, hogy a mentális kórállapotok megnevezésére a diagnosztikus célokra használt nemzetközi nozológiai rendszerek - a mentális kórállapotok etiológiájának tisztázatlanságai és ellentmondásai miatt - a "zavarok" (disorders) szót alkalmazzák „betegség” helyett. Marie Jahoda osztrák származású amerikai pszichológus 1958-ban megjelent, a pozitív mentális egészségről szóló könyvében tudományos igénnyel elemezte a lelki egészség (mental health) és a lelki/mentális betegség (mental illness) közti konceptuális különbségeket. A korabeli szakirodalom alapján hat empirikus mutatót javasolt a "pozitív mentális egészség” vizsgálatára: önkép (self, beleértve a vonásokat, motivációt, érzelmeket, érdeklődést és értékeket); fejlődés és kibontakozás; integráltság, autonómia, valóságészlelés, valamint a környezethez történő alkalmazkodás (Jahoda, 
1958). Buda Béla szociálpszichológiai aspektusból kísérelte meg a két fogalom elkülönítését (Buda, 1994). A legújabb nemzetközi áttekintés (Manwell és mtsai, 2015) szerint e fogalmak használata tükrözi a beszélő személy rendszerint implicit módon használt elméletét a kettő viszonyáról, amelynek négy különböző változatát az 1. ábra mutatja be.

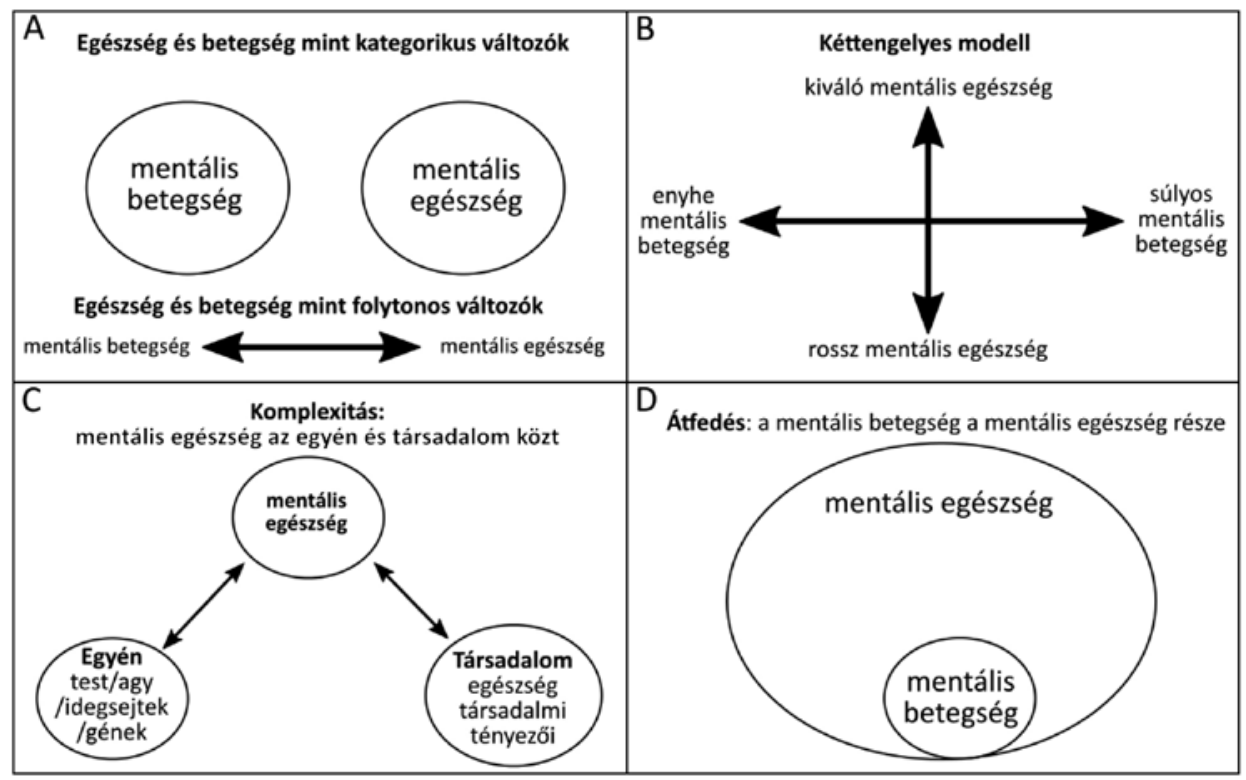

1. ábra. A mentális egészség és betegség eltérő szemléleteit tükröző modellek négy különböző változata („,pozicionalitás”)

(Manwell és mtsai, 2015, 7. o. nyomán)

\subsection{A mentális egészség átfogó témakörei}

A mentális állapot („mentális egészség”) populációs vizsgálatai igen szerteágazóak elméleti háttér és módszertan, és - ezekből következően - eredmények vonatkozásában egyaránt. Az elméleti és módszertani diverzitás nehezíti, sőt lehetetlenné teszi a különféle populációkban kapott eredmények összehasonlítását és a követéses vizsgálatokat. A konszenzus hiánya okán kanadai szerzők a közelmúltban nemzetközi szakértők bevonásával kétkörös kvalitatív tematikus felmérésben vizsgálták meg és összegezték a mentális egészség koncepcionális szintjeit, amelyeket 2015-ben megjelent közleményükben négy átfogó témakörbe soroltak (Manwell és mtsai, 2015) (2. ábra). A „paradigmák/elméletek/modellek” blokkba kerültek azok a szemléleti keretek, amelyek a releváns kutatások kiindulópontjául szolgálnak, pl. bio-pszicho-szociális modell, életminőség, reziliencia, kibontakozás/örömállapot (flourishing), evolúciós teóriák, ökológiai modell, stb. 
A „pozicionalitás” blokkba sorolták azokat a lehetséges kinyilvánított (explicit) vagy rejtett (implicit) szemléleti alapokat, amelyek a kutatók mentális egészséggel kapcsolatos tudományos világnézetét jellemzik. A különböző tudományos világnézeteket, „pozíciókat” tükröző konceptuális modellek változatait az 1. ábra mutatja be részletesen. Az "alapfogalmak” (core concepts) tartalmazzák a kutatások során vizsgálható, egyénekre jellemző konstruktumokat és faktorokat. Az ábrán az egyértelmúség kedvéért ezek angol elnevezéseit is feltüntettük. A negyedik blokkban kaptak helyet a "társas/környezeti faktorok", amelyek embercsoportok, közösségek vagy társadalmak vonatkozásában vizsgálandók, elkülönítve az egyéneket jellemző faktoroktól. A 2. ábra nyilai a négy elméleti blokk közötti összefüggéseket ábrázolják a szakértői vélemények alapján. Ezek szerint a mentális állapottal kapcsolatos explicit tudományos világnézet (pozicionalitás) meghatározza azon elméleteket és modelleket, amelyekből a vizsgálni kívánt konstruktumok (alapfogalmak) származtathatók. Azonban az alkalmazott elméletekből és modellekből is visszakövetkeztethető a kutató nem kinyilvánított (implicit) pozicionalitása. A tudományos világnézet (pozicionalitás) és a modellek alapján meghatározott alapfogalmak hatással vannak a társas tényezókre, azok pedig visszahatóan maguk is alakítják a konstruktumokat. A szerzők megállapítása szerint a mentális egészségnek nincs olyan átfogó modellje, amely nemzetközileg elfogadottnak, általánosan használtnak volna tekinthető. A mentális egészségre vonatkozó különféle kutatások eredményei jelentősen különböznek aszerint, hogy a kutatók milyen elméleti keret alapján tervezték meg a vizsgálatot, ezért adott vizsgálat eredményeinek értelmezéséhez annak elméleti hátterét ismerni kell.

\subsection{Személyiség vagy környezet}

A mentális egészség vizsgálata kapcsán egy évszázada, az USA haderejének 1. világháborús toborzásakor merült fel tömegesen a kérdés, hogy azt a személyiség tartós jellemzői, vagy inkább a környezetben zajló pillanatnyi események befolyásolják. A kérdés tudományos vizsgálatát azonban csak a Gordon Allport által útnak indított vonáselmélet (Allport, 1927) évtizedekkel későbbi kibontakozása és érvényes mérőeszközök birtokában lehetett elkezdeni. A szakmai vita jelenleg sem lezárt arról, hogy a mentális egészséget és a viselkedést milyen mértékben befolyásolják a biológiailag meghatározott, illetve a társas helyzetek hatására kialakult pszichés jellemzók, de az bizonyos, hogy mindkettő szerepe jelentős (Plomin, DeFries, \& Fulker, 1988), amint azt az 1. ábra C-modellje, valamint a 2. ábra "Társas/környezeti tényezők" blokkja mutatja. A mentális állapot tudományos igényú, populációs vizsgálatainak tervezése során kell eldönteni, hogy az alapkérdés(ek) megválaszolásához milyen mértékben szükséges a személyiség jellemzőire 
és múködésére, illetve a társas-környezeti tényezőkre összpontosítani. Az utóbbi vonatkozásában iránymutatónak tekinthető az Egészségügyi Világszervezet 2008-ban közzétett modellje (WHO, 2008) az egészség társadalmi meghatározó tényezőiről és ezek kapcsolódásáról (3. ábra). A mentális egészség populációs szintú vizsgálata során érdemes legalább a társas öszszetartozás (social cohesion) valamely aspektusára adatokat gyújteni.

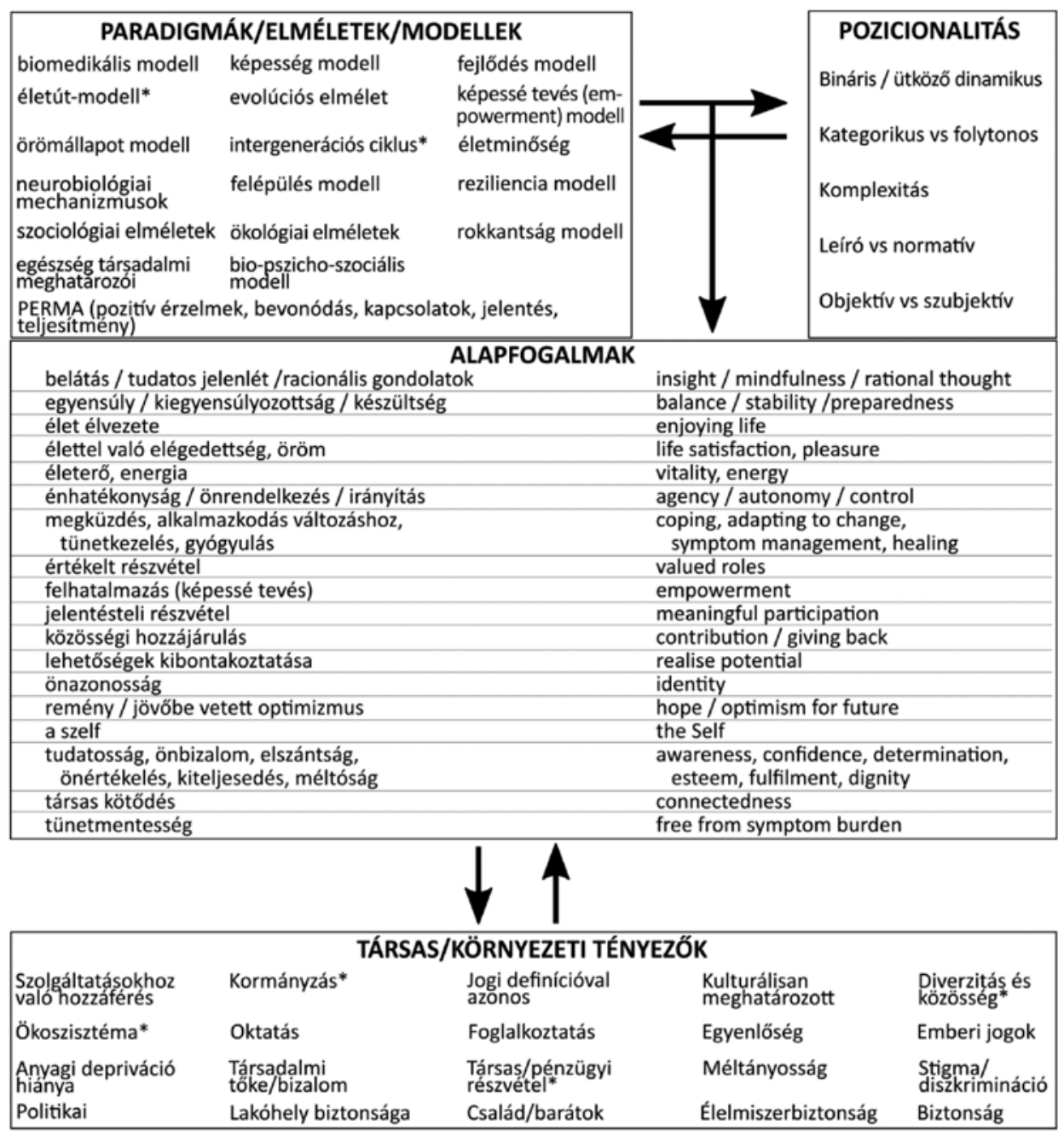

2. ábra. A mentális egészség átfogó témakörei (Manwell és mtsai, 2015, 4. o. nyomán)

Megjegyzés: * E tényezőket a résztvevők mint hiányzókat jelölték meg. 


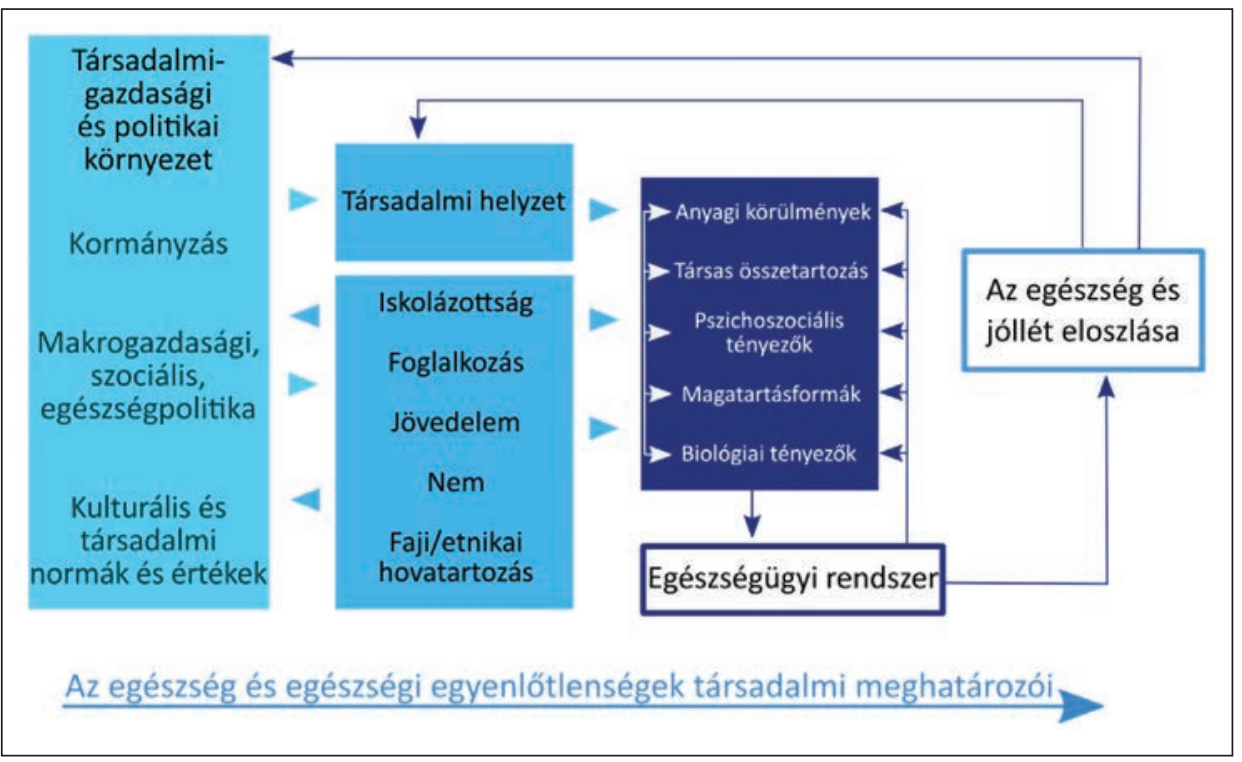

3. ábra. Az egészség és egészségi egyenlőtlenségek társadalmi meghatározó tényezői az Egészségügyi Világszervezet szerint (WHO, 2008, 43. o. nyomán)

\subsection{Objektív vagy szubjektív mérés}

Az 1970-es években az USA-ban végzett vizsgálatok során (Breslow, 1972) derült fény arra, hogy a mentális egészség vizsgálata nem alapozható kizárólag szakértők által végzett, objektív mérésekre; ahhoz a vizsgált személy saját egészségéről alkotott szubjektív véleménye, önértékelése is hozzátartozik. Azóta az önértékelés nemcsak a mentális állapot különféle aspektusai, hanem az általános egészség vizsgálata tekintetében is széles körben alkalmazott, megbízható módszerré vált (Ahmad, Jhajj, Stewart, Burghardt, \& Bierman, 2014). A mentális egészség ugyan a testi (fizikai, szomatikus) egészségtől elkülöníthető faktora az egészségnek, de a fizikai állapot jellemzése is hozzátartozik, különösen, ha a lelki egészséget, illetve a mentális állapotot a betegellátás kimeneti mutatójaként kívánják vizsgálni. Ezt a későbbiekben ismertetendő Medical Outcomes Study (MOS) eredményei bőségesen alátámasztották.

\subsection{Az időablak jelentősége}

A mentális állapot időben jelentősen változik egészséges és beteg személyek körében is. Emiatt minden epidemiológiai vizsgálatnak tekintetbe kell vennie az időfaktort: információt kell gyújteni a mentális betegség, illetve 
állapot fennállásának időtartamáról, illetve az előfordulás meghatározott időintervallumon belüli gyakoriságáról. Ennek módja a kérdésben azon időpont vagy időtartam meghatározása, amelynek vonatkozásában a mentális állapotról/betegségről nyilatkozni kell. Ez lehet a válaszadás időpontja (pl. NHP, M.I.N.I. egyes kérdései), az elmúlt két hét (pl. GHQ-12, PHQ-9, WHOQoL), az elmúlt 30 nap (pl. HRQoL, Kessler-6, SF-36 egyes kérdései), az elmúlt év, vagy a teljes élettartam (pl. DIS, CIDI egyes kérdései). A kérdések idői dimenziója alapján a kóros állapotok vonatkozásában különféle prevalenciaértékek számolhatók. A pontprevalencia azt fejezi ki, hogy adott időpontban a populáció mekkora hányadánál állt fenn az adott betegség. Az időtartam-prevalencia vonatkozhat az elmúlt 30 napra, vagy az elmúlt 12 hónapra, megadva, hogy a meghatározott időperióduson belül bármikor a vizsgált népesség mekkora hányada szenvedett a kérdéses betegségben; illetve az élettartam-prevalencia a betegségnek a vizsgálat időpontjáig bármikori, legalább egyszeri előfordulását mutatja a vizsgált populációban (NIMH, 2017). Mentális betegségek esetén csakúgy, mint más betegségeknél, minél hosszabb időtávra vonatkozik a prevalencia, annál magasabb az értéke: az európai régió magas jövedelmú országaiban a mentális betegségek múlt évi prevalenciája 17,1\%, élettartam-prevalenciája pedig 35,2\% (Steel és mtsai, 2014). A testi betegségek esetén gyakran használt incidenciamutatók a mentális zavarok vonatkozásában - a kezdetre vonatkozó pontos információk hiánya és a diagnosztikai problémák miatt - ritkán használatosak.

\subsection{Normalitás mint statisztikai átlag vagy morálfilozófiai fogalom}

A normalitás jól ismert fogalma a tudomány számos ágának, amelynek azonban két eltéró jelentése van. A kvantitatív módszereket alkalmazó tudományokban a normalitást statisztikai értelemben használják, amely szerint az adott jellemző normális eloszlása megmutatja, hogy annak értékei vagy kategóriái a vizsgált népességben milyen gyakorisággal fordulnak elő. A leggyakrabban előforduló érték vagy kategória definíciószerúen a „normális", amely ebben a kontextusban leíró jelleggel bír. Számos különféle biológiai és pszichés jellemző statisztikailag normális eloszlást mutat, és az eloszlásból e jellemző́k paraméterei (1́gy a leggyakoribb, „normális” is) kiszámíthatók (Fidy \& Makara, 2005).

A normalitásnak létezik azonban egy másik, morálfilozófiai értelmezése is. Ennek értéktartalma van, és arra vonatkozik, hogy adott jellemzőnek mi volna a normatív (optimális vagy kívánatos) mértéke, vagyis ebben az öszszefüggésben preskriptív, előíró jellegú. A normális mint átlagos, illetve a normális mint optimális vagy kívánatos pszichés jellemzők közti különbségre Jahoda is felhívta a figyelmet fentebb említett munkájában (Jahoda, 1958). 
A mentális betegségek előfordulásának felmérésére irányuló epidemiológiai vizsgálatokban olyan, a kóros állapotokra vonatkozó kérdő́iveket szokás használni, amelyekre vonatkozóan ismertek a referenciaértékek, vagyis létezik olyan leválasztási pont (határérték) és/vagy olyan kategóriarendszer, amelyek alkalmazásával a „normális” és „kóros” személyek elkülöníthetók.

A nem kóros állapotokat vizsgáló kérdőívek esetén a referenciaérték öszszehasonlítási célokra hasznos, de nem nélkülözhetetlen; ilyenkor a vizsgálat ismétlése szolgáltathat információt az adott populáció állapotának változásáról. A „normális mint átlagos” vagy „normális mint kívánatos” közti különbséget azonban a mentális egészség populációs mutatóinak értelmezésekor is szem előtt kell tartani. A fogalom tartalmának tisztázása nélkül nem értelmezhetó például a 4. ábra adatsora, amely a depresszió gyakoriságának négyszeres különbségét mutatja európai országok közt (Rai, Zitko, Jones, Lynch, \& Araya, 2013).

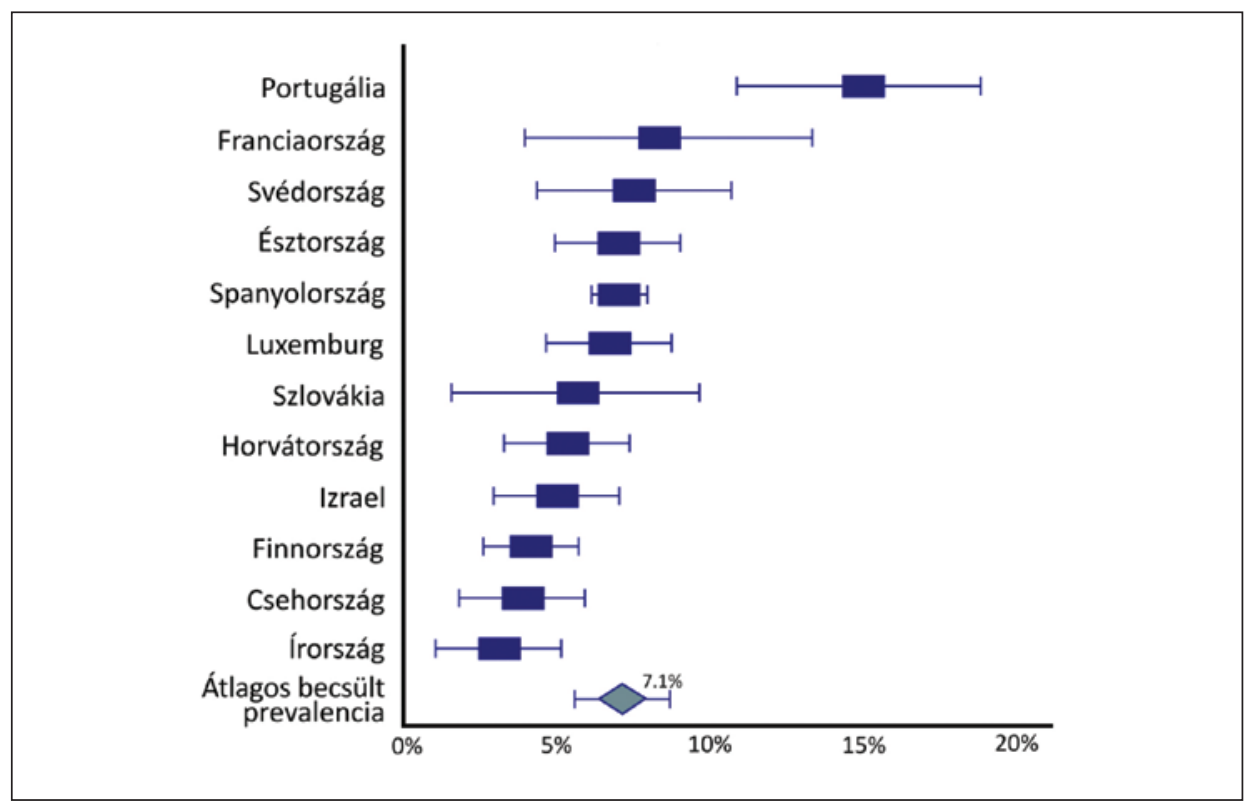

4. ábra. A depresszió becsült prevalenciája magas jövedelmú országokban

(Rai és mtsai, 2013, 198. o. nyomán)

\section{Mit mérünk?}

A mentális állapot populációs vizsgálata során döntően konstruktumokat (közvetlenül nem mérhető mentális és/vagy viselkedéses funkciókat vagy ezek halmazát) kell mérni (ld. a 2. ábra „Alapfogalmak” blokkját), amelyek- 
nek kidolgozása és az azokhoz tartozó mérőeszközök kifejlesztése a pszichometria tárgya. A konstruktumok mellett szükség van olyan osztályozási rendszerre, amely lehetővé teszi az utóbbiak egységes alapelvek szerinti azonosítását és kategóriába sorolását a vizsgálandó populáció teljes körében, elkülöníthetóvé téve a kóros és nem kóros állapotokat. Ez a betegségek egységesen használt osztályozási rendszere alapján lehetséges, amelyet a mentális zavarok tekintetében két nozológiai rendszer is segít, a Betegségek Nemzetközi Osztályozása (BNO, jelenleg a BNO-10), (NM GYÓGYINFOK, 1995) valamint a Mentális Betegségek Diagnosztikai és Statisztikai Kézikönyve (DSM, jelenleg a DSM-5) (APA, 2013).

Megemlítendő, hogy mind a BNO, mind a DSM a betegségek kategorikus megközelítését alkalmazza, amelynek értelmében meghatározott betegség - a diagnosztizálásához számba veendó kritériumok alapján - vagy fennáll, vagy sem. Bizonyos zavarok, például az autizmus és a skizofrénia esetében azonban - a legújabb idegtudományi kutatások eredményei alapján - a DSM-5 a betegségek diagnosztikus osztályozásának folytonos (dimenzionális vagy spektrum) megközelítését alkalmazza.

\subsection{A mentális betegségek/zavarok populációs mérésének eszközei}

A pszichiátria és klinikai pszichológia által elterjedten használt diagnosztikus eszközök kapacitás- és időigényük miatt nem használhatók populációs felmérésekben; azokhoz más eszközöket kell alkalmazni. Ezek kifejlesztésére az USA-ban az 1970-es években merült fel az igény, a törvényhozás által a mentális zavarokban szenvedőkre vonatkozó első nagyszabású epidemiológiai adatgyújtés elrendelése kapcsán (Carter, 1977). A diagnosztikus eszközök alkalmazási korlátai és a DSM bizonyos módszertani problémái miatt olyan új eszközt kellett kidolgozni kifejezetten a felmérés céljaira, amely strukturált diagnosztikus interjú formájában lehetővé tette a legfontosabb mentális zavaroknak az akkoriban érvényes DSM-III szerinti diagnózisának felállítását. Ez volt a Diagnostic Interview Schedule (DIS), amelynek alkalmazására először az Epidemiologic Catchment Area (ECA) Study néven ismertté vált felmérés keretében, 1980-1985 közt került sor (Robins, Helzer, Croughan, \& Ratcliff, 1981). Hazánkban Szádóczky és munkatársai végeztek először pszichiátriai epidemiológiai vizsgálatot a DIS használatával (Szádóczky és mtsai, 1996). A DIS nemzetközi alkalmazását azonban korlátozta, hogy a DSM-III-ra épült, ezért szükséges volt a továbbfejlesztése úgy, hogy a BNO alapján is lehetővé tegye a mentális betegségek azonosítását. E követelménynek felelt meg a DIS átdolgozásával kifejlesztett, szintén teljesen strukturált Composite International Diagnostic Interview (CIDI) (Robins 
és mtsai, 1988), amely nemcsak az USA-ban, hanem más országokban is alkalmazható volt a mentális betegségek gyakoriságának pontos, és országok közti összehasonlításra is megfelelő becslésére (Cottler, 1990). A CIDI későbbi továbbfejlesztése lehetővé tette, hogy a mentális betegségek kockázati tényezőire, következményeire, és a kezeléssel összefüggó tényezőkre is lehessen adatokat gyújteni. E továbbfejlesztett változatot használták az 1998-ban indult World Mental Health (WMH) Survey eszközeként (WMHCIDI). ${ }^{2}$

Sajnálatos módon a CIDI-nek nincs magyar nyelvú változata, ezért Magyarország nem tud részt venni azokban a nemzetközi vizsgálatokban, amelyek ezt az eszközt használják. A klinikai pszichológiában használható magyar nyelvú eszközök gyújteménye elérhető a szakmai közönség számára (Perczel-Forintos, Ajtay, Barna, Kiss, \& Komlósi, 2012).

A DIS 36, a CIDI 21 a mentális zavar élettartam-, múlt évi és múlt havi prevalenciájának becslésére alkalmas, de mindkettő alkalmazásának korlátja, hogy felvételét erre kiképzett személynek kell végeznie, és hogy a diagnosztikus interjú időtartama meglehetősen hosszú, egy-két óra. A jelentős erőforrás-igény az oka annak, hogy a mentális zavarok pontos megállapítására szolgáló eszközök nem, vagy csak korlátozottan alkalmasak populációs felmérésekre. A nemzetközi összehasonlítást és beavatkozások tervezését lehetővé tevő felmérésekhez azonban általában nincs is szükség diagnózisok helyszíni megállapítására; elegendő a leggyakoribb zavarokat és/ vagy állapotokat felmérni vagy szúrni, amihez egyszerúbb eszközök is megfelelőek. A mentális zavarok populációs gyakoriságának megállapítására leggyakrabban használt, teljesen strukturált diagnosztikus és szúrőkérdőívek listáját az 1. táblázat tartalmazza.

2 The World Mental Health Survey Initiative. Letöltve: 2018. 01. 10-én: http:/ /www.hcp.med. harvard.edu/wmhcidi/instruments_capi.php 


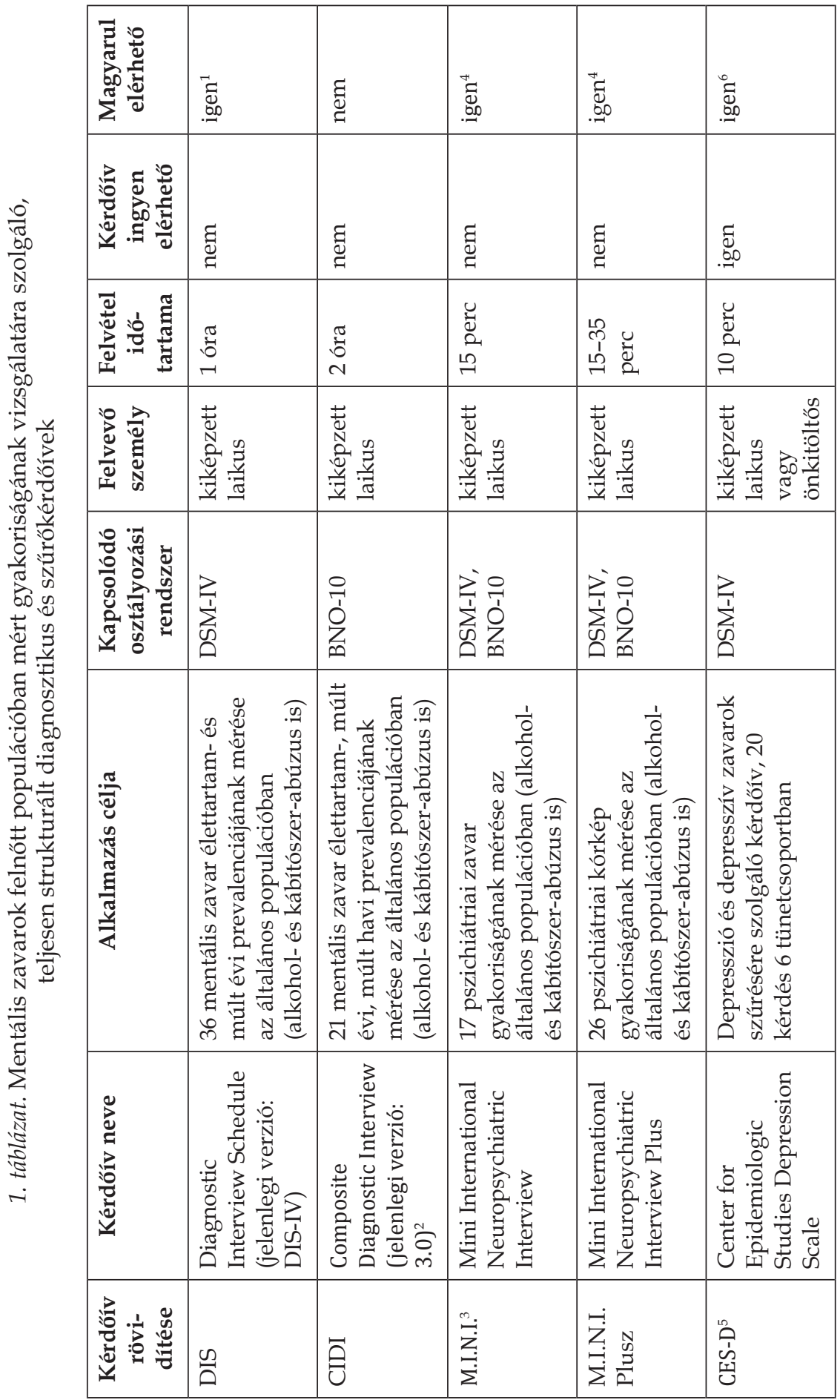




\begin{tabular}{|c|c|c|c|c|c|}
\hline 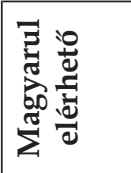 & ש్ & 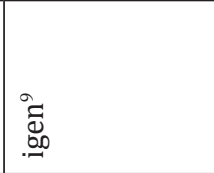 & $\begin{array}{l}7 \\
\tilde{0} \\
.00 \\
.00\end{array}$ & $\begin{array}{l}7 \\
\approx 0 \\
.00 \\
.00\end{array}$ & $\underset{0.0}{0}$ \\
\hline 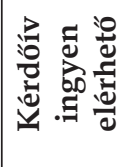 & $\underset{0.00}{0.0}$ & ॄ્વ & ש્ฮ & 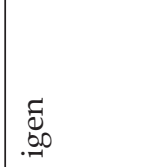 & $\underset{\Xi}{\Xi}$ \\
\hline 离 & 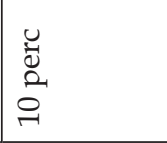 & 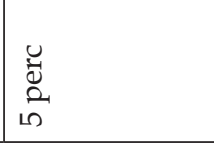 & 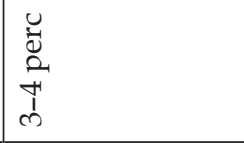 & 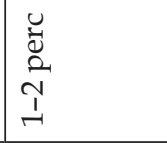 & $\frac{u}{0}$ \\
\hline 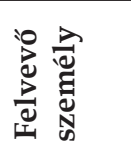 & 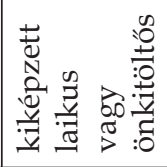 & 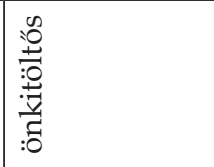 & $\begin{array}{l}0 \\
: 0 \\
: 0 \\
: 0 \\
: \cdot 0 \\
0 \\
0 \\
: 0\end{array}$ & $\begin{array}{l}: 0 \\
: 0 \\
: 0 \\
: 0 \\
: 0 \\
0 \\
0 \\
: 0\end{array}$ & $\begin{array}{l}n \\
: 0 \\
: 0 \\
: 0 \\
: \frac{1}{2} \\
: 0 \\
: 0\end{array}$ \\
\hline 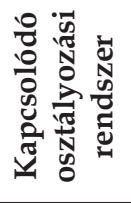 & $\sum_{\text {Dn }}^{n}$ & 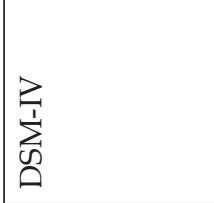 & $\sum_{\substack{1 \\
0}}^{B}$ & $\sum_{0}^{B}$ & 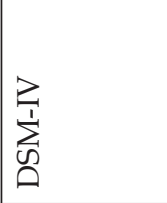 \\
\hline 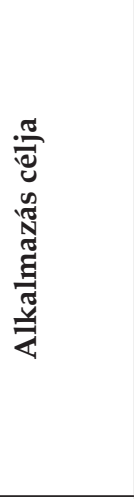 & 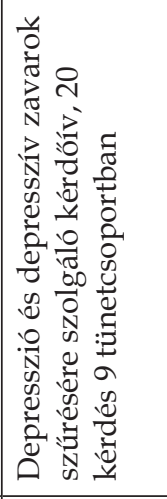 & 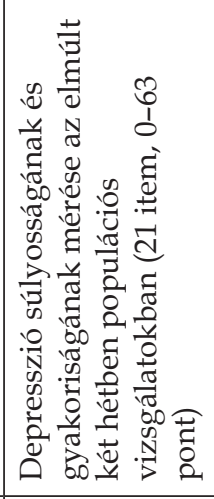 & 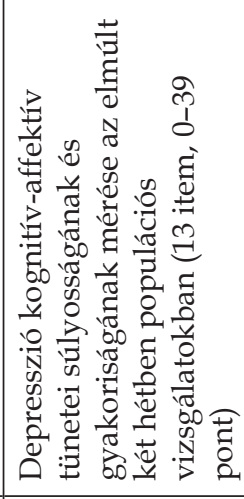 & 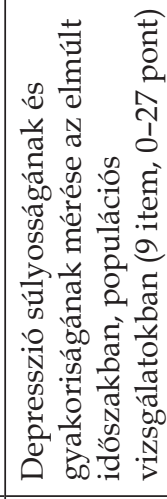 & 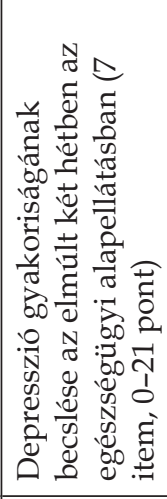 \\
\hline 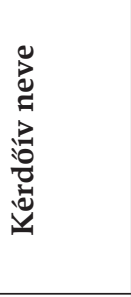 & 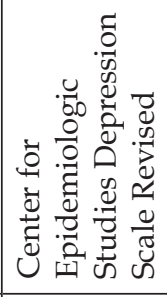 & 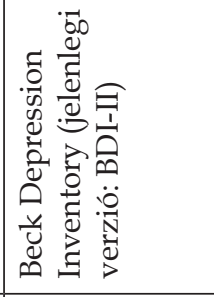 & 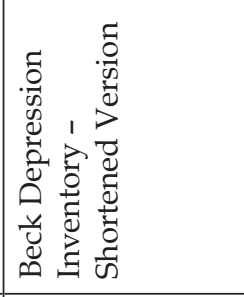 & 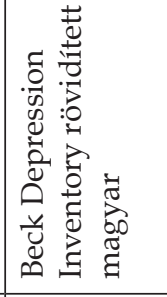 & 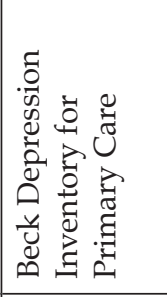 \\
\hline 逽 & $\begin{array}{l}\hat{\alpha} \\
\text { ầ } \\
\text { ஸ્木 }\end{array}$ & $\stackrel{\infty}{\stackrel{\infty}{\overline{1}}}$ & 竞 & 它: & 官司苛 \\
\hline
\end{tabular}




\begin{tabular}{|c|c|c|c|c|c|c|}
\hline 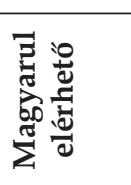 & $\begin{array}{l}\stackrel{2}{\overrightarrow{0}} \\
.000 \\
.00\end{array}$ & 矛 & 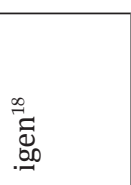 & 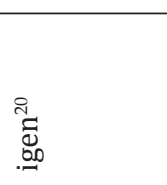 & $\begin{array}{l}\widetilde{D} \\
.0 .0\end{array}$ & 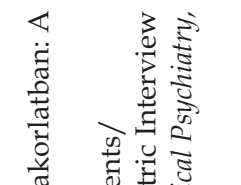 \\
\hline 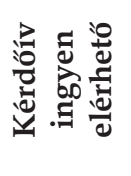 & $\tilde{\Xi ્ ષ ~}$ & $\underset{\mathscr{D}}{\mathscr{D}}$ & 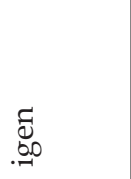 & $\underset{D}{\mathbb{D}}$ & 赵 & 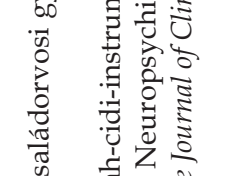 \\
\hline 选递 & $\begin{array}{l}u \\
\grave{d} \\
a \\
a \\
\infty\end{array}$ & 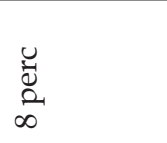 & $\begin{array}{l}0 \\
\dot{d} \\
\stackrel{2}{1} \\
\stackrel{1}{r}\end{array}$ & 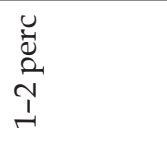 & 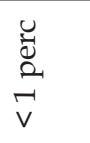 & 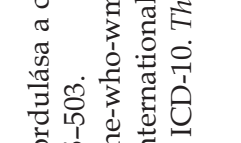 \\
\hline 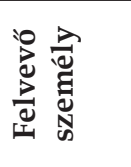 & 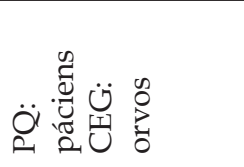 & 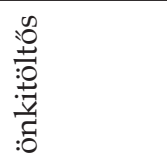 & 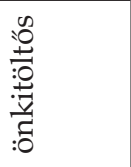 & 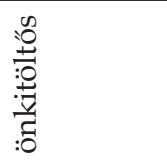 & 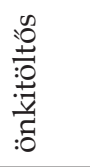 & 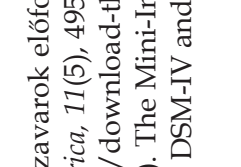 \\
\hline 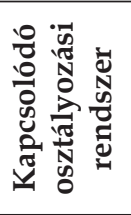 & $\sum_{\substack{1 \\
\text { D }}}^{1}$ & $\sum_{\substack{n \\
D}}^{1}$ & $\sum_{\substack{1 \\
D}}^{1}$ & $\sum_{\substack{n \\
\text { I }}}^{1}$ & $\sum_{\substack{1 \\
D}}^{M}$ & 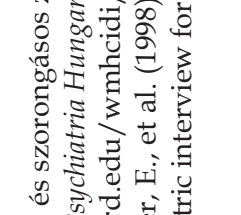 \\
\hline 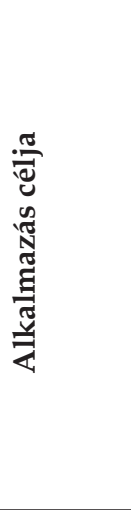 & 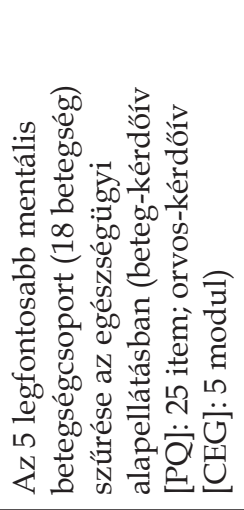 & 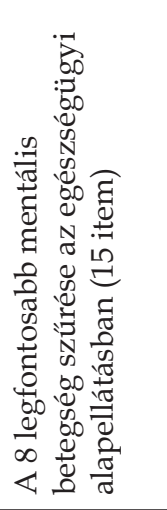 & 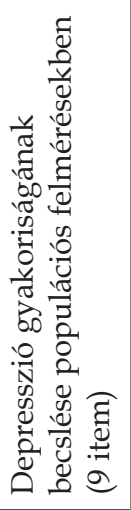 & 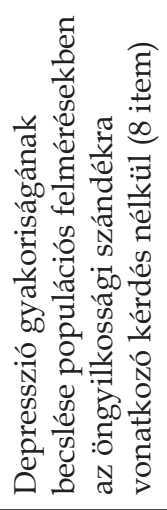 & 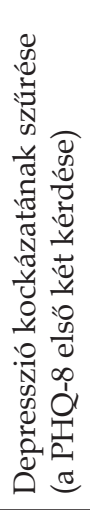 & 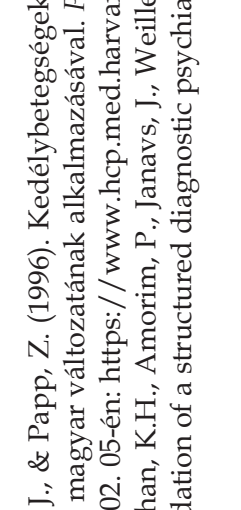 \\
\hline 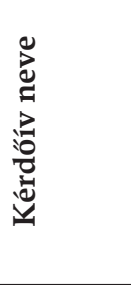 & 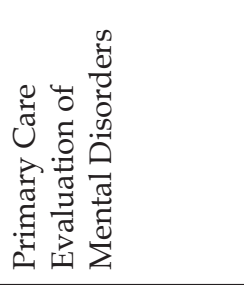 & 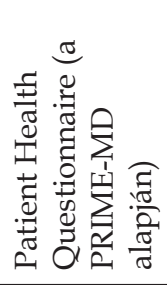 & 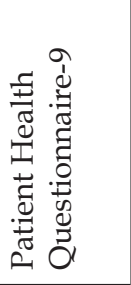 & 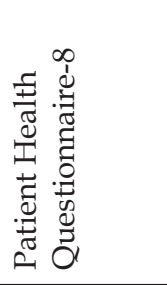 & 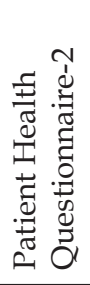 & 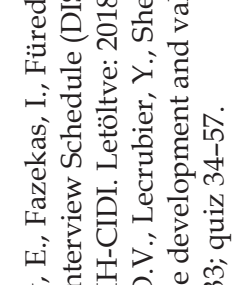 \\
\hline 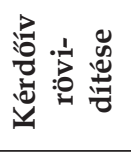 & 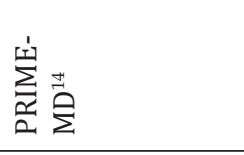 & 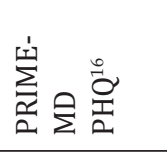 & 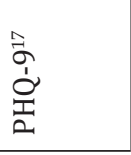 & $\begin{array}{l}\text { के } \\
\vdots \\
\vdots \\
\underline{1} \\
2\end{array}$ & 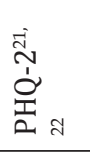 & 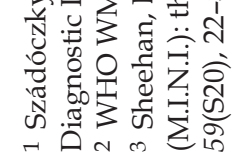 \\
\hline
\end{tabular}




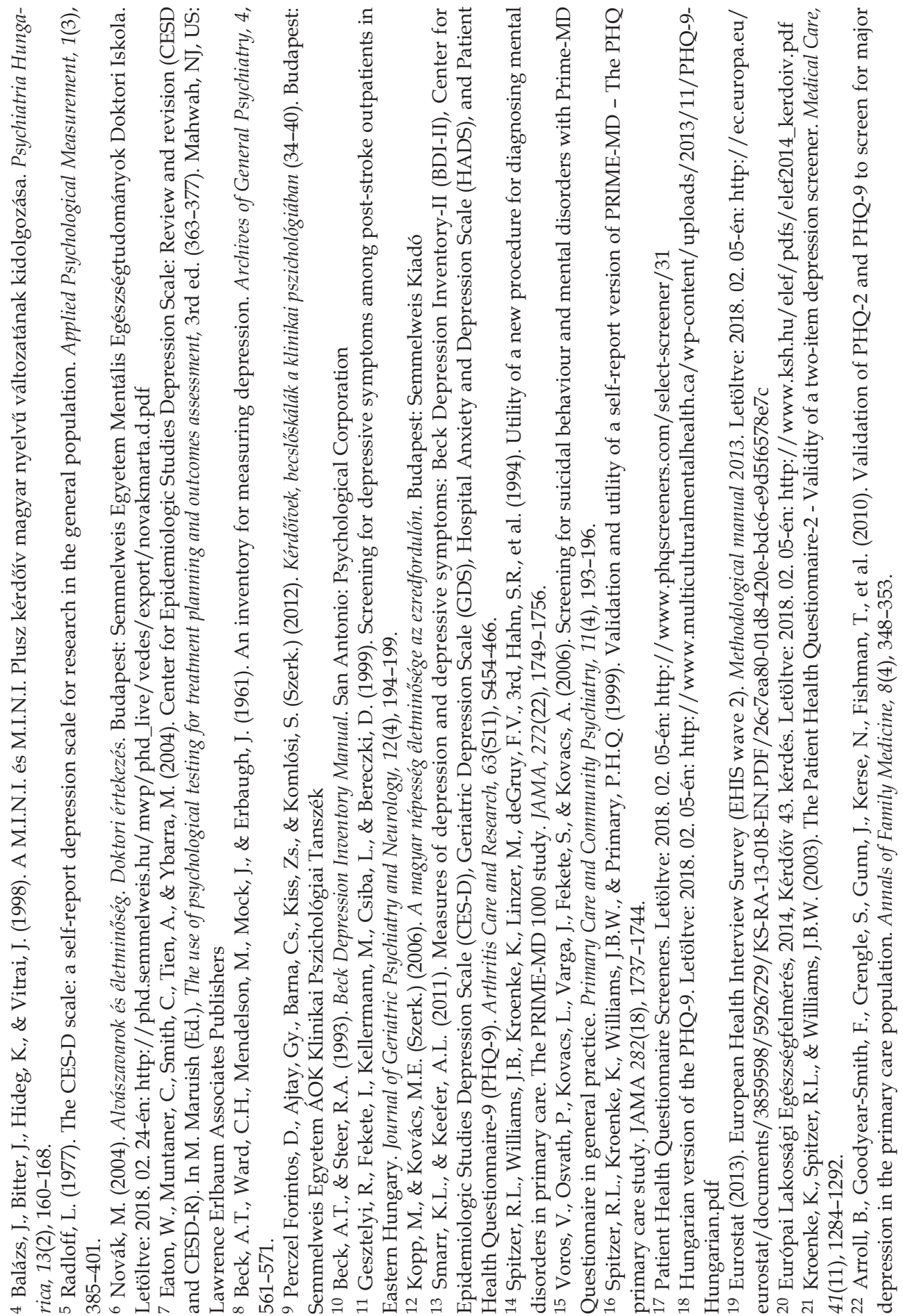


A mentális zavarok epidemiológiai vizsgálatához új szemponttal szolgáltak azok az elemzések, amelyek e zavarok jelentős komorbiditására keresték a választ. Komplex statisztikai módszerrel elemeztek nagy mintaelemszámú, komorbid mentális zavarok gyakoriságát vizsgáló amerikai (Krueger, Caspi, Moffitt, \& Silva, 1998) és holland (Vollebergh és mtsai, 2001) mintákat, amelyek alapján a diagnosztikus kategóriák mögött két, illetve három látens faktort sikerült azonosítani, egyszerúbb és részben közös oki struktúrát sejtetve. E szerzők a leggyakoribb mentális zavarokat a tünetek megjelenése szerint „internalizáló” és „externalizáló” csoportokba sorolják; sőt a holland csoport szerint az internalizáló zavarok is elkülöníthetők annak alapján, hogy inkább szorongás-szenvedés, vagy inkább félelem a vezető tünet (5. ábra).

\begin{tabular}{|c|c|c|c|c|c|c|c|c|}
\hline \multicolumn{7}{|c|}{ INTERNALIZÁLÓ ZAVAROK } & \multirow{2}{*}{\multicolumn{2}{|c|}{$\begin{array}{l}\text { EXTERNALIZÁLÓ ZAVAROK } \\
\text { szerrel összefüggő zavarok }\end{array}$}} \\
\hline \multicolumn{3}{|c|}{ szorongás-szenvedés } & \multicolumn{4}{|c|}{ félelem } & & \\
\hline disztímia & $\begin{array}{l}\text { major } \\
\text { depressziv } \\
\text { epizód }\end{array}$ & $\begin{array}{c}\text { generalizált } \\
\text { szorongásos } \\
\text { zavar }\end{array}$ & $\begin{array}{l}\text { szociális } \\
\text { fóbia }\end{array}$ & $\begin{array}{l}\text { egyszerũ } \\
\text { fóbia }\end{array}$ & $\begin{array}{l}\text { agora- } \\
\text { fóbia }\end{array}$ & $\begin{array}{l}\text { pánik- } \\
\text { zavar }\end{array}$ & $\begin{array}{c}\text { drog- } \\
\text { függöség }\end{array}$ & alkoholfüggőség \\
\hline
\end{tabular}

5. ábra. A mentális betegségek háromdimenziós modellje (Vollebergh és mtsai, 2001, nyomán)

A mentális betegségek látens változókat tartalmazó modellje elsősorban a kutatási adatok elemzési stratégiájára van hatással, és nemcsak a komorbid állapotok etiológiájának feltárására, hanem a komorbiditás kialakulásának előrejelzésére is alkalmas lehet, amint arra a World Mental Health Survey adatain végzett elemzés utalt (Kessler, Petukhova, \& Zaslavsky, 2011).

\subsection{Az általános mentális állapot vizsgálatának eszközei}

A mentális állapot felmérésére alkalmas eszközök fejlesztésében jelentős szerepet játszottak azok a vizsgálatok, amelyek krónikus betegek életminóségét és annak a betegellátást követő javulásának mértékét kívánták megbecsülni.

Az egészségügyi ellátás eredményességének megítélésére és populációs vizsgálatokra is alkalmas első, máig széles körben használt és magyarul is elérhető eszköz, a Nottingham Health Profile (NHP) fejlesztése az 1970-es évek közepén kezdődött Nagy-Britanniában, és 1985-re fejeződött be. A két részből álló profil első részének 38 iteme 6 területet fed le, úgymint alvás, fizikális mozgékonyság, energia, fájdalom, érzelmi reakció és társas elszigetelődés. A második rész a mindennapi életnek az egészségi állapottal leginkább összefüggő dimenzióit vizsgálja (Hunt, McEwen, \& McKenna, 1985). 
Itt említendő, hogy az „egészségprofil”, valamint „egészség-index” kifejezéseknek specifikus jelentésük van. Az egészségi állapot jellemezhetó úgy, hogy annak tartományai (mentális, testi, spirituális, társas, stb.) közül 1) csak egyet vizsgálnak és azt mutatják be; 2) minden egyes tartományt vizsgálnak, és a gyújtött információk tartományonként elkülönülten kerülnek bemutatásra, ez esetben egészség-profilról van szó; vagy pedig 3) az egyes tartományokba tartozó adatokat valamilyen képlettel egyetlen mutatóvá alakítják, amelyet egészség-indexnek neveznek (Earl-Slater, 1999).

A betegellátás eredményességének vizsgálatai közül kiemelendő az 1986ban indult Medical Outcomes Study (MOS) (Tarlov és mtsai, 1989), amelynek célja az volt, hogy a betegellátásból kikerülő páciensek állapotjavulásának magyarázó tényezőit (pl. ellátási infrastruktúra; az orvos szakképzettsége, technikai és interperszonális készségei) feltárja, valamint a betegek állapotának nyomon követésére az orvosi gyakorlatban jól használható eszközöket fejlesszen ki. Az eszközökre a klinikai kimenetet jellemző testi, lelki és társas funkcionalitás, a beteg szubjektív egészsége és jólléte, valamint a kezeléssel való elégedettség mérése érdekében volt szükség. A MOS-ban alkalmazott mérőeszköz kérdéseit a későbbiekben számos további skála megalkotásához átvették, ezért azt részletesebben ismertetjük.

A MOS vizsgálatot alapos előkészítés előzte meg, amelynek során támaszkodtak korábbi vizsgálatokra, így az 1974-1982 közt megvalósított egészségbiztosítási kísérletre (Health Insurance Experiment, HIE), amely a különféle egészségbiztosítási módoknak az ellátás igénybevételére gyakorolt hatását tanulmányozó, addigi legnagyobb szabású, azóta is hivatkozott vizsgálata volt (Brook és mtsai, 2006). A HIE-ben résztvevők állapotának felmérésére fejlesztették ki egyebek közt a 38 itemból álló Mental Health Inventory-t (MHI) a mentális egészség vizsgálatára. A kérdőív a pszichés distressz és a jóllét mérésére alkalmas; megerősítő faktoranalízis szerint e két fő faktora van, valamint 5, egymással összefüggő alfaktora (szorongás, depresszió, érzelmi kapcsolatok, általános pozitív affektus, viselkedéses / érzelmi kontrollvesztés) (Veit \& Ware, 1983).

A MOS előkészítése során a betegek funkcionalitásának és életminőségének mérésére egy 116 törzskérdésből és 33 kiegészítő kérdésból álló kérdőívet dolgoztak ki, amelynek kérdéseit 8 részbe (section) sorolták (Hays, Sherbourne, \& Mazel, 1995). A kérdőív 5. része tartalmazza az MHI összes (38) itemét.

A MOS résztvevőinek beválogatásához egy 20 kérdésből álló rövid kérdőívet dolgoztak ki, amely a testi és mentális egészség jellemzését is szolgálta; ez volt az SF-20 (Short Form-20). ${ }^{3}$ Amikor annak differenciáló képessége elégtelennek bizonyult, kibővítésével hozták létre az SF-36 kérdőív

3 Medical Outcomes Study: 20-Item Short Form Survey Instrument (SF-20). Letöltve: 2018.02.05-én: https://www.rand.org/health/surveys_tools/mos/20-item-short-form/survey-instrument.html 
1.0 változatát ${ }^{4}$ amelynek kérdéseit a MOS 116 törzskérdése közül válogatták. A mentális egészség mérésére 5 olyan kérdést választottak ki az MHIból, amelyek a legpontosabban bejósolták a teljes, 38 kérdésből álló MHI összpontszámát (Davies, Sherbourne, Peterson, \& Ware, 1988).

Az SF-36 nyolc általános egészségtartomány (úgymint testi funkcionalitás, szerepkorlátozottság testi probléma miatt, testi fájdalom, önészlelt általános egészség, életerő [vitalitás], társas múködés, szerepkorlátozottság érzelmi probléma miatt, mentális egészség) mérésére alkalmas kérdőív (Ware, Snow, Kosinski, \& Gandek, 1993), és bevezetése óta számos vizsgálatban került alkalmazásra (Ware, 2000). A RAND által ajánlott értékelés lehetővé teszi az SF-36 (pontos nevén: RAND SF-36 ver 1.0) használatát bárki számára, de emellett van egy másik változata is (SF-36 ver2), amely az értékelés módjában különbözik a szabadon felhasználható változattól (normalizált pontszámokat generál); ez utóbbi csak kereskedelmi forgalomban érhető el. Az SF-36-nak 12 tételes változata is létezik, amelynek használatához az Optum Inc. engedélye szükséges. ${ }^{5}$

Az eredeti 116 tételes MOS-kérdóív, a 38 tételes MHI kérdooív és az SF-20 kérdőív is szabadon elérhetó a vizsgálatot kivitelező RAND Corporation honlapján. ${ }^{6}$ A MOS 5. részében szereplő, érzelmi múködésre vonatkozó MHI-kérdések közül származik az SF-36-ba is beválogatott kérdéseket tartalmazó MHI-5 kérdőív, amelynek több vizsgálat bizonyította a validitását a hangulatzavarok szúrésére (Rumpf, Meyer, Hapke, \& John, 2001; van den Beukel és mtsai, 2012). Az EU a tagállamai számára használatra ajánlott európai egészség-indikátorokról (European Core Health Indicators) 2010-ben megjelentetett irányelvében az MHI-5-öt ajánlotta a pszichés distressz, és a szintén a MOS, illetve az SF-36 kérdéseiból származó Energia és Vitalitás (EVI) skálát javasolta a pozitív lelki egészség vizsgálatára (utóbbi itemeit ld. a 2. táblázatban csillaggal jelölve) (Eurostat, 2010). A 2013-ban ugyanezen témában megjelentetett riport azonban már nem tartalmazott ajánlást e skálák használatára, hanem további fejlesztést tartott szükségesnek - egyebek közt a kelet-európai országokban kapott eltérő eredmények miatt (European Commission, 2013). A MOS eszközéból származó skálákat azonban jelenleg is használják nemzetközi kutatásokban. Ezek itemeinek viszonyát a 2. táblázat mutatja be.

\footnotetext{
4 36-Item Short Form Survey Instrument (SF-36). Letöltve: 2018.02.05-én: https:/ /www.rand.org/ health/surveys_tools/mos/36-item-short-form/survey-instrument.html

5 SF-12v2 Health Survey. Optum Inc. http://campaign.optum.com/optum-outcomes/what-wedo/health-surveys/sf-12v2-health-survey.html

6 RAND Corporation. https://www.rand.org/
} 
2. táblázat. A MOS, az SF-36 és az MHI kérdőívek tételeinek összevetése

\begin{tabular}{|c|c|c|c|c|c|}
\hline & $\begin{array}{c}\text { MOS } \\
\text { itemek } \\
\text { száma }\end{array}$ & $\begin{array}{c}\text { MOS } \\
\text { item } \\
\text { sorszáma }\end{array}$ & $\begin{array}{c}\text { SF-36 } \\
\text { item } \\
\text { sorszáma }\end{array}$ & $\begin{array}{l}\text { MHI-38 } \\
\text { item } \\
\text { sorszáma }\end{array}$ & $\begin{array}{c}\text { MHI-5 } \\
\text { item } \\
\text { sorszáma }\end{array}$ \\
\hline \multicolumn{6}{|c|}{ 1. rész: Egészség és napi tevékenységek } \\
\hline szubjektív egészség & 1 & 1 & $1(\operatorname{MOS} 1)$ & & \\
\hline $\begin{array}{l}\text { testi fájdalom az elmúlt } \\
\text { hónapban }\end{array}$ & 1 & 2 & 21 (MOS 2) & & \\
\hline $\begin{array}{l}\text { egészségproblémák hatá- } \\
\text { sa a társas múködésre }\end{array}$ & 1 & 3 & $20(\operatorname{MOS} 3)$ & & \\
\hline $\begin{array}{l}\text { egészség az egy évvel } \\
\text { ezelőttihez képest }\end{array}$ & - & - & 2 & & \\
\hline \multicolumn{6}{|l|}{ 2. rész: Testi egészség } \\
\hline Napi tevékenységek & 10 & 4 & $\begin{array}{c}\text { 3-12 (MOS } \\
\text { 4.a-j) }\end{array}$ & & \\
\hline Elégedettség testileg & 1 & 5 & & & \\
\hline Önállóság utazáskor & 1 & 6 & & & \\
\hline Mozgásképesség & 1 & 7 & & & \\
\hline $\begin{array}{l}\text { Lelki problémák egészség } \\
\text { miatt }\end{array}$ & 11 & 8 & $\begin{array}{c}23 \text { (MOS } \\
8 . \mathrm{e})^{*} \\
27(\mathrm{MOS} \\
8 . \mathrm{c})^{*} \\
29(\mathrm{MOS} \\
8 . \mathrm{a})^{*} \\
31(\mathrm{MOS} \\
8 . \mathrm{i})^{*}\end{array}$ & & \\
\hline Testi tünetek & 8 & 9 & & & \\
\hline \multicolumn{6}{|l|}{ 3. rész: Fájdalom } \\
\hline Testi fájdalom & 1 & 10 & & & \\
\hline Fájdalom gyakorisága & 1 & 11 & & & \\
\hline Fájdalom időtartama & 1 & 12 & & & \\
\hline Fájdalom hatásai & 6 & 13 & $\begin{array}{l}22(\mathrm{MOS} \\
13 . \mathrm{d})\end{array}$ & & \\
\hline Fájdalom átlagos mértéke & 1 & 14 & 21 & & \\
\hline $\begin{array}{l}\text { Fájdalom legnagyobb } \\
\text { mértéke }\end{array}$ & 1 & 15 & & & \\
\hline
\end{tabular}




\begin{tabular}{|c|c|c|c|c|c|}
\hline & $\begin{array}{c}\text { MOS } \\
\text { itemek } \\
\text { száma }\end{array}$ & $\begin{array}{c}\text { MOS } \\
\text { item } \\
\text { sorszáma }\end{array}$ & $\begin{array}{c}\text { SF-36 } \\
\text { item } \\
\text { sorszáma }\end{array}$ & $\begin{array}{l}\text { MHI-38 } \\
\text { item } \\
\text { sorszáma }\end{array}$ & $\begin{array}{l}\text { MHI-5 } \\
\text { item } \\
\text { sorszáma }\end{array}$ \\
\hline \multicolumn{6}{|c|}{ 4. rész: Mindennapi múködési szint } \\
\hline $\begin{array}{l}\text { Testi problémákkal } \\
\text { összefüggő múködési } \\
\text { szint }\end{array}$ & 7 & 16 & $13-16$ & & \\
\hline $\begin{array}{l}\text { Érzelmi problémákkal } \\
\text { összefüggő múködési } \\
\text { szint }\end{array}$ & 3 & 17 & $\begin{array}{c}17 \text { (MOS } \\
17 . a) \\
18 \text { (MOS } \\
17 . b) \\
19 \text { (MOS } \\
17 . c)\end{array}$ & & \\
\hline $\begin{array}{l}\text { Egészség és otthoni } \\
\text { munka }\end{array}$ & 1 & 18 & & & \\
\hline $\begin{array}{l}\text { Egészség és fizetésért } \\
\text { végzett munka }\end{array}$ & 1 & 19 & & & \\
\hline 5. rész: Érzelmek & 38 & $20-57$ & $\begin{array}{c}24 \text { (MOS } \\
27) \\
25 \text { (MOS } \\
44) \\
26(\mathrm{MOS} \\
34) \\
28 \text { (MOS } \\
36) \\
30 \text { (MOS } \\
51)\end{array}$ & $\begin{array}{l}1-38 \\
\text { (MOS } \\
20-57)\end{array}$ & $\begin{array}{c}1 \text { (MOS } \\
27) \\
2 \text { (MOS } \\
44) \\
3 \text { (MOS } \\
34 \text { ) } \\
4 \text { (MOS } \\
36) \\
5 \text { (MOS } \\
51)\end{array}$ \\
\hline $\begin{array}{l}\text { 6. rész: Társas } \\
\text { tevékenységek }\end{array}$ & 3 & $58-60$ & $\begin{array}{c}20 \\
32(\mathrm{MOS} \\
58)\end{array}$ & & \\
\hline $\begin{array}{l}\text { 7. rész: Egészség } \\
\text { megítélése }\end{array}$ & 8 & 61 & $\begin{array}{c}33 \text { (MOS } \\
\text { 61.g) } \\
34 \text { (MOS } \\
61 . \mathrm{e}) \\
35 \text { (MOS } \\
61 . \mathrm{h}) \\
36 \text { (MOS } \\
61 . \mathrm{f})\end{array}$ & & \\
\hline 8. rész: Alvás & 9 & 62 & & & \\
\hline
\end{tabular}

Megjegyzés: * A MOS-ban, illetve az SF-36-ban szereplő, csillaggal jelölt tételek később „Energia és Vitalitás Skála (EVI)” néven önállóan is használatba kerültek. 
A mentális állapot (és általában az egészségi állapot) vizsgálata és jellemzése nem árul el semmit arról, hogy egy adott tünet, kóros állapot vagy funkciócsökkenés milyen módon befolyásolja a páciens mindennapi életét és múködését. Ennek megközelítésére került kidolgozásra az egészséggel összefüggő életminőség fogalma az életminőség átfogó tartományán belül. (Az életminőség vizsgálata az élet minden dimenziójának kutatását megköveteli, ami az egészségügyi ellátás és szükségletek vonatkozásában rendszerint túl nagy feladat.) Az egészséggel összefüggő életminőség csak az egészség/betegség hatását írja le a mindennapi életre, a testi, lelki és társas múködésre. Az ezt vizsgáló eszközök változatai a szomatikus és mentális egészségre vonatkozó kérdéseket egyaránt tartalmaznak (Yin, Njai, Barker, Siegel, \& Liao, 2016).

Az epidemiológiai felmérésekben és az egészségügyi ellátásban az általános mentális állapot, illetve az egészséggel összefüggő életminőség vizsgálatára leggyakrabban használt kérdőíveket a 3. táblázat összegzi. 


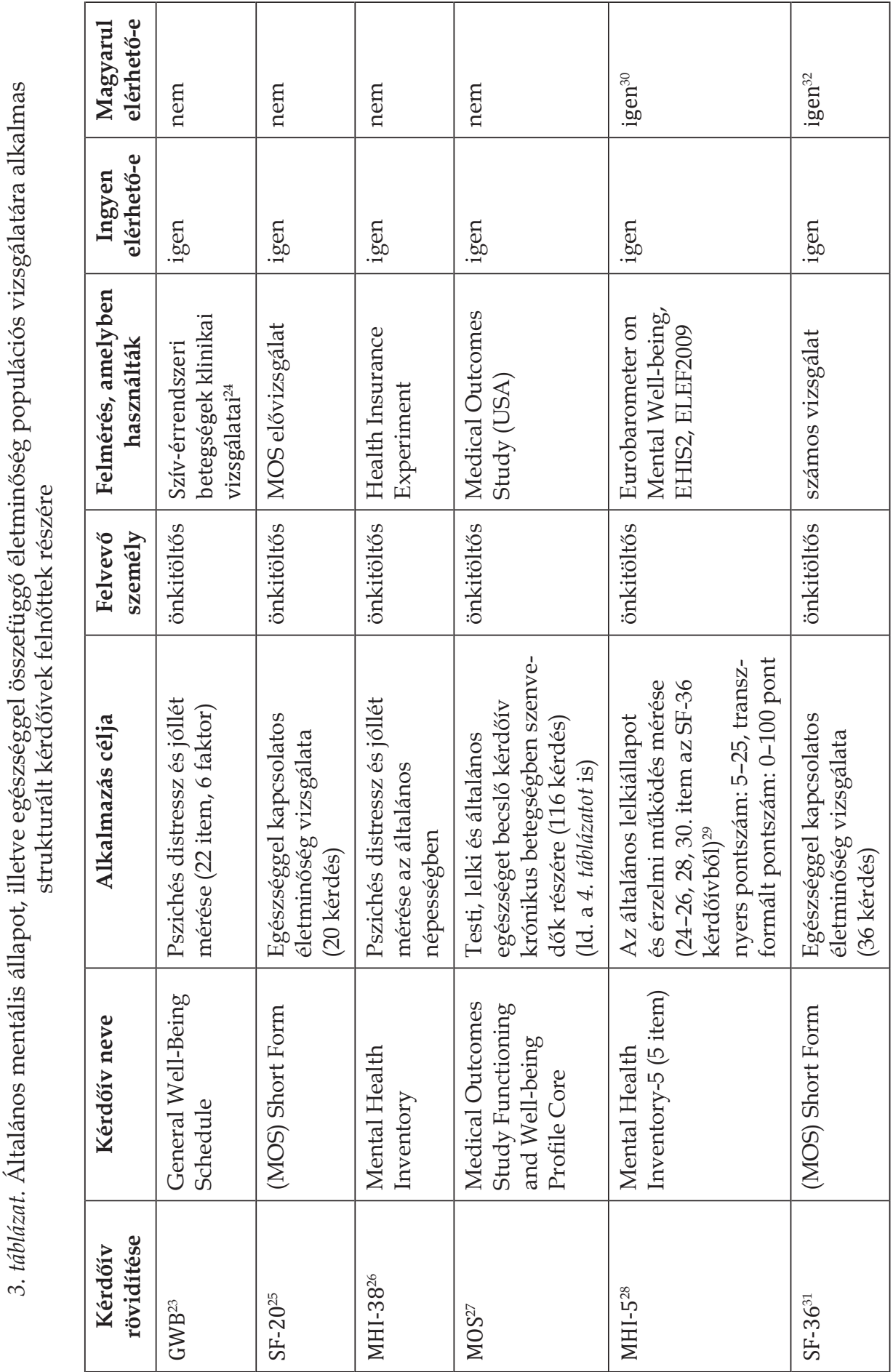




\begin{tabular}{|c|c|c|c|}
\hline 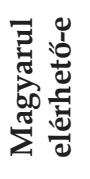 & م્ & $\underset{.0}{5}$ & $\begin{array}{l}\tilde{D} \\
.00\end{array}$ \\
\hline 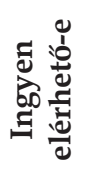 & $\underset{\mathscr{D}}{\mathscr{D}}$ & 矛 & . \\
\hline 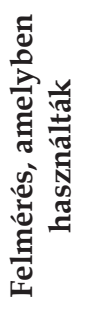 & 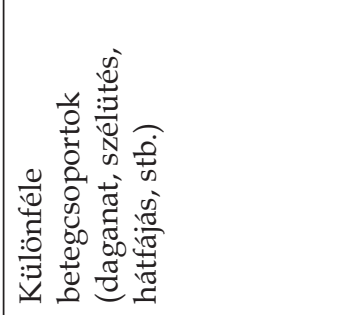 & 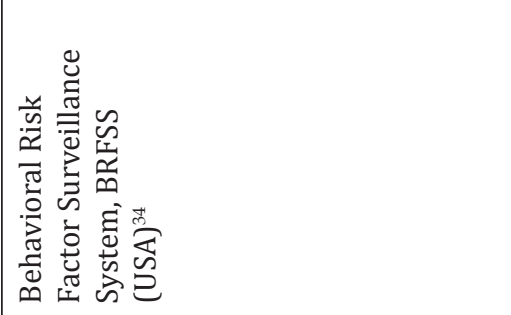 & 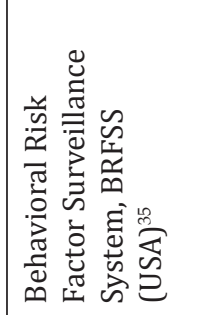 \\
\hline 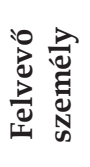 & 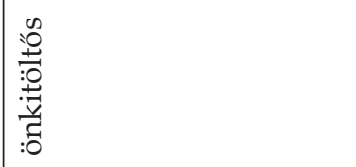 & 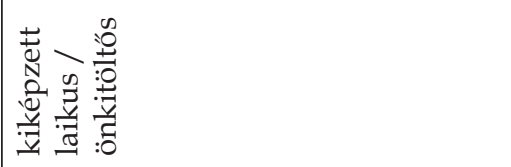 & 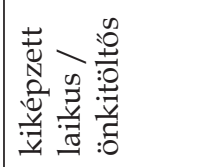 \\
\hline 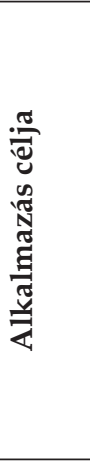 & 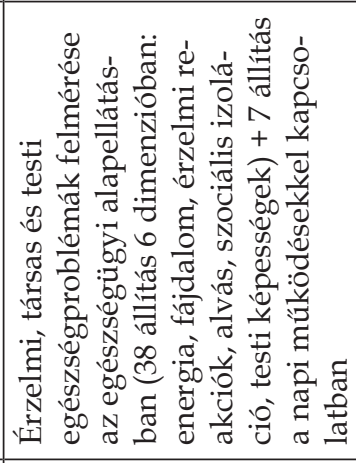 & 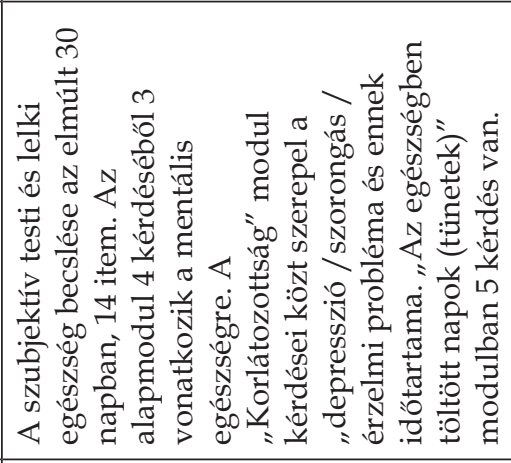 & 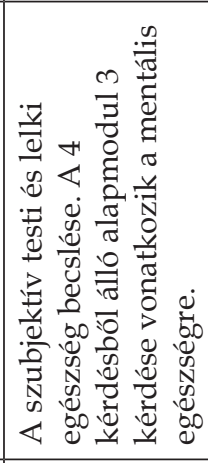 \\
\hline 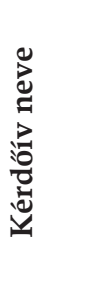 & 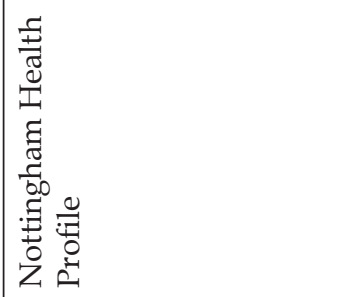 & 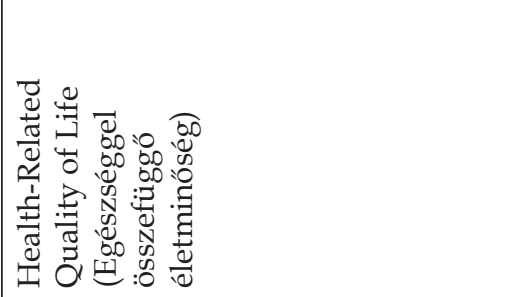 & 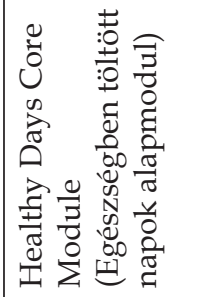 \\
\hline 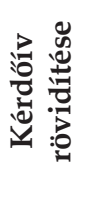 & 吾 & $\begin{array}{l}\overrightarrow{0} \\
\stackrel{0}{1} \\
\underline{1} \\
\underline{1}\end{array}$ & 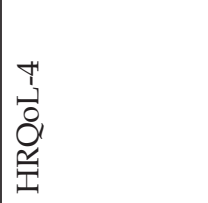 \\
\hline
\end{tabular}




\begin{tabular}{|c|c|c|c|c|c|c|}
\hline 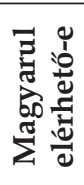 & 赵 & 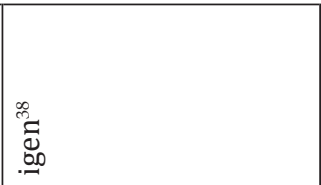 & 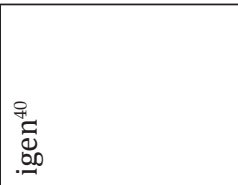 & $\begin{array}{l}7 \\
\stackrel{7}{0} \\
.00\end{array}$ & E્વ & $\begin{array}{l}\text { 声 } \\
\stackrel{0}{0} \\
.00\end{array}$ \\
\hline 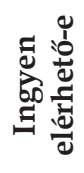 & $\underset{d}{0}$ & $\underset{d}{\mathbb{D}}$ & 赵 & 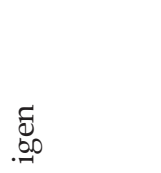 & 赵 & 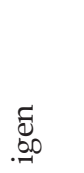 \\
\hline 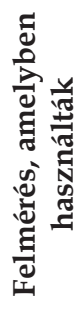 & 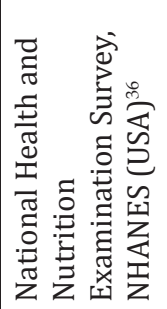 & 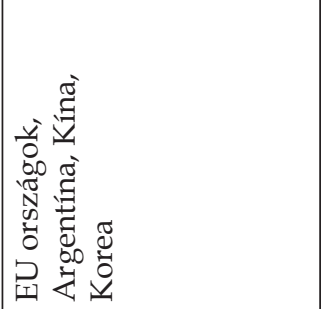 & 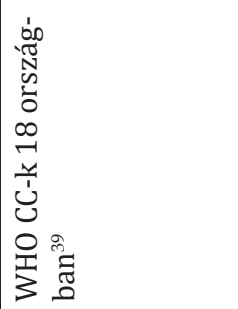 & 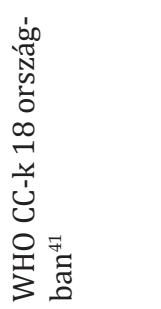 & 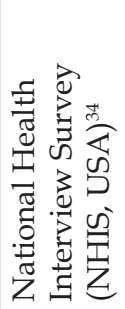 & 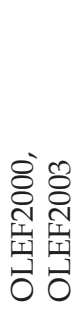 \\
\hline 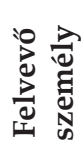 & 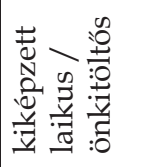 & 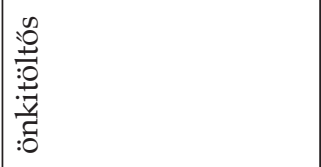 & 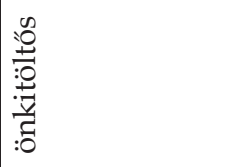 & 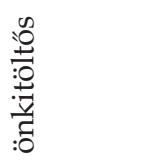 & 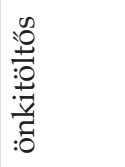 & 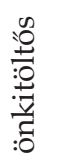 \\
\hline 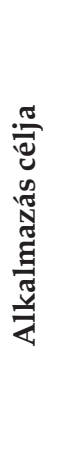 & 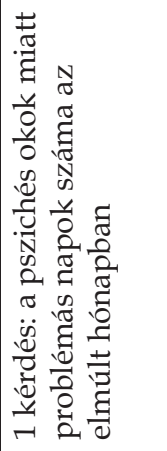 & 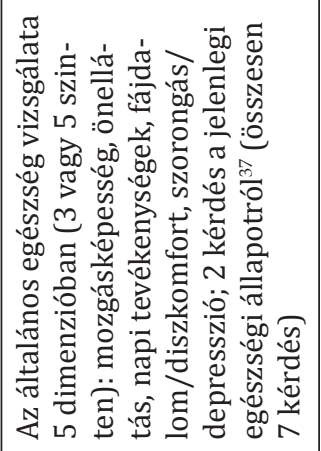 & 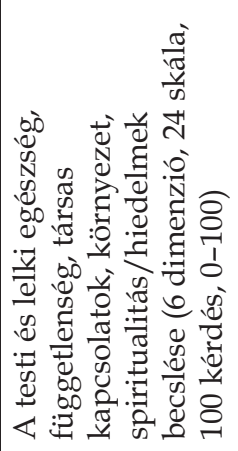 & 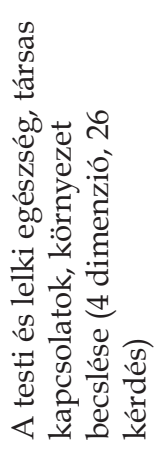 & 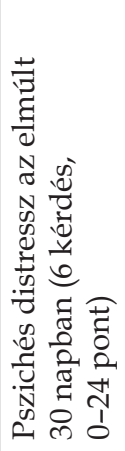 & 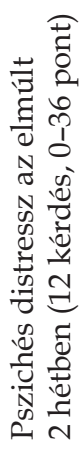 \\
\hline 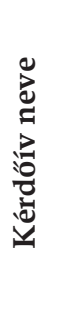 & 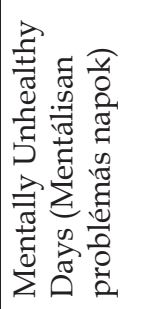 & 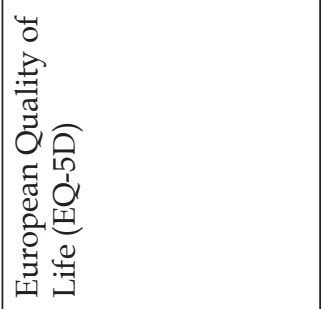 & 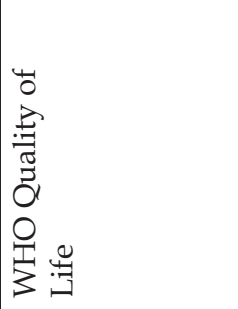 & 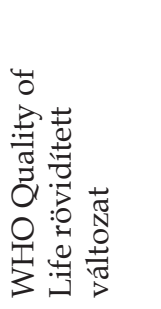 & 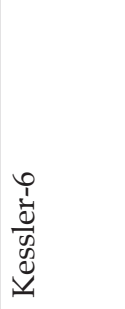 & 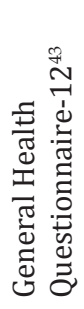 \\
\hline 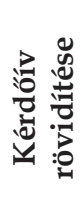 & 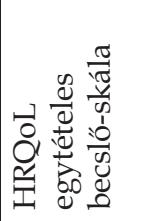 & \begin{tabular}{c}
0 \\
0 \\
0 \\
0 \\
0 \\
\multicolumn{3}{|c|}{} \\
1
\end{tabular} & $\begin{array}{l}8 \\
8 \\
7 \\
1 \\
0 \\
0 \\
0 \\
0 \\
1 \\
3 \\
3\end{array}$ & 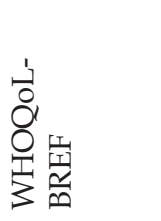 & 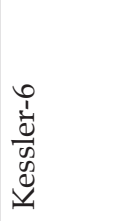 & $\begin{array}{l}\stackrel{1}{7} \\
\stackrel{1}{\mathfrak{d}} \\
\stackrel{0}{0}\end{array}$ \\
\hline
\end{tabular}




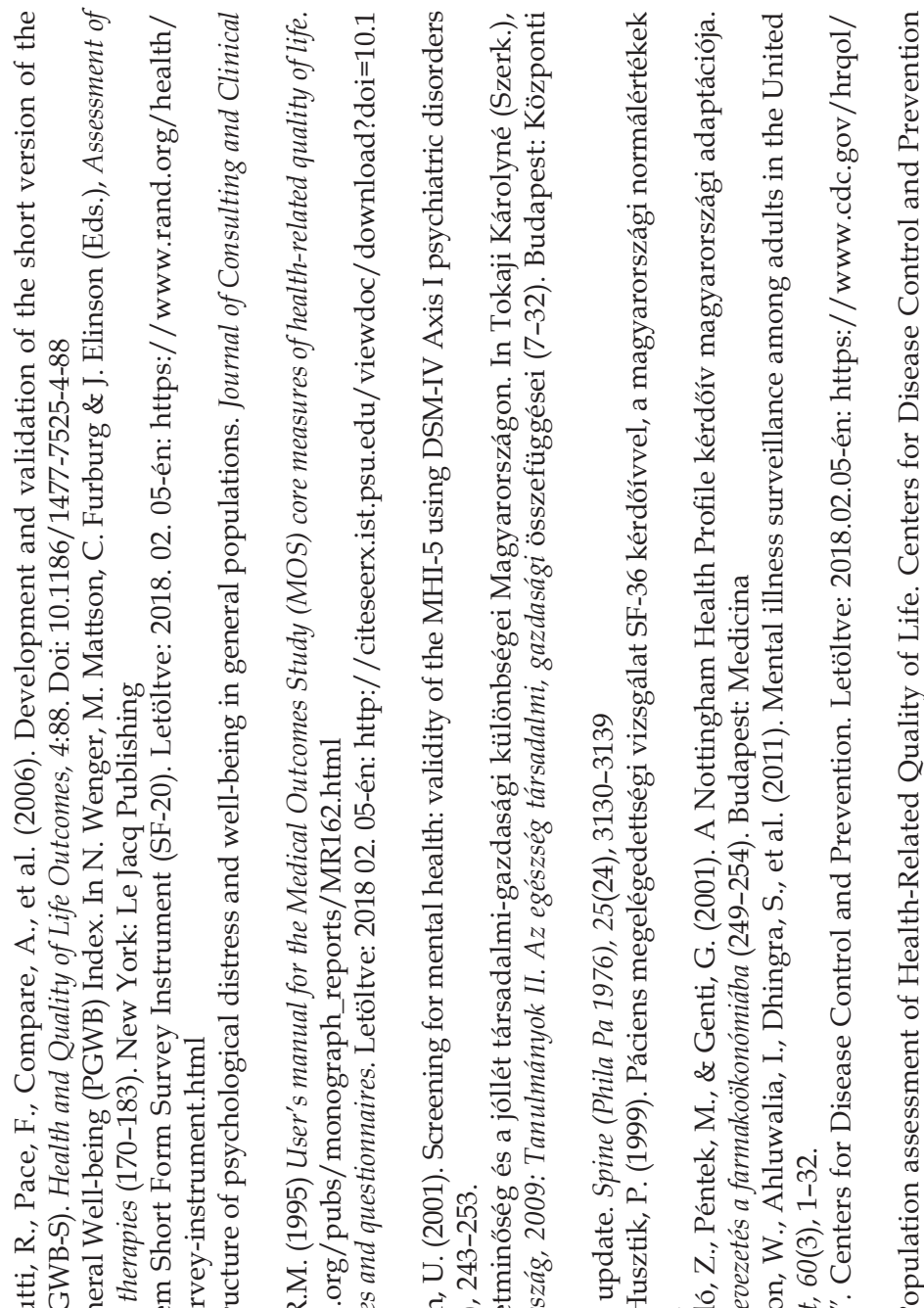

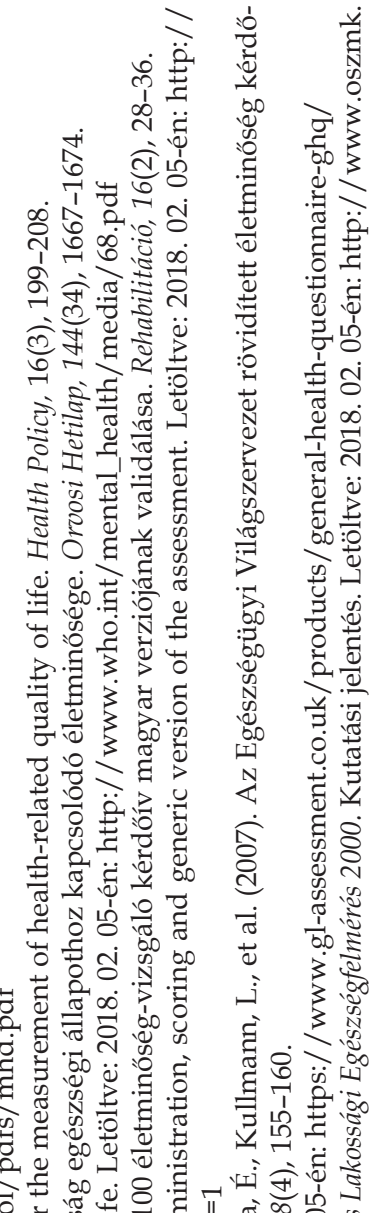

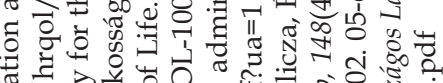

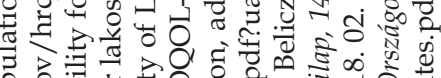

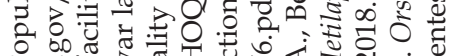

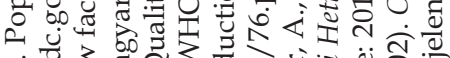
m.

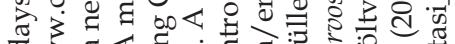

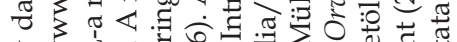

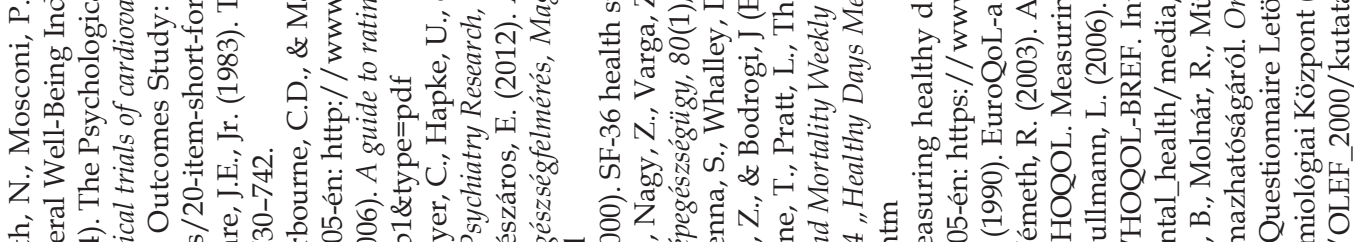

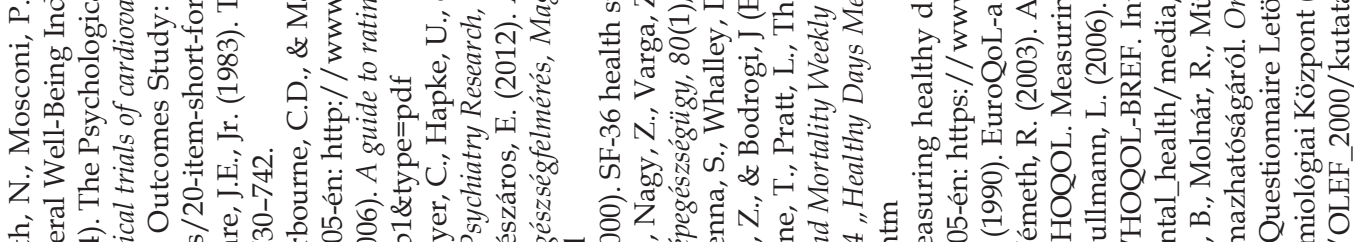

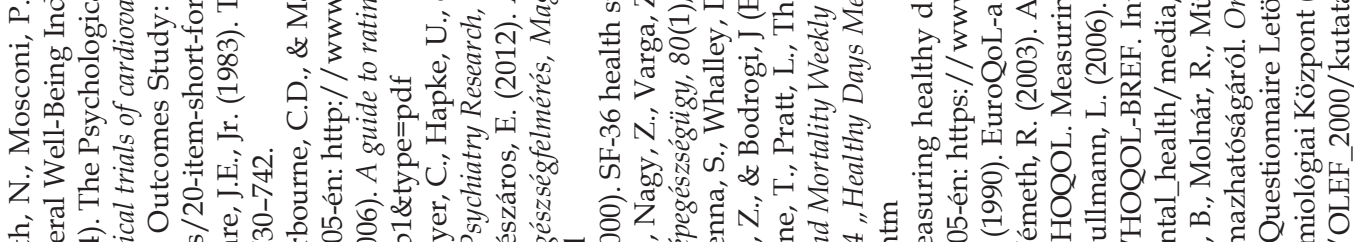

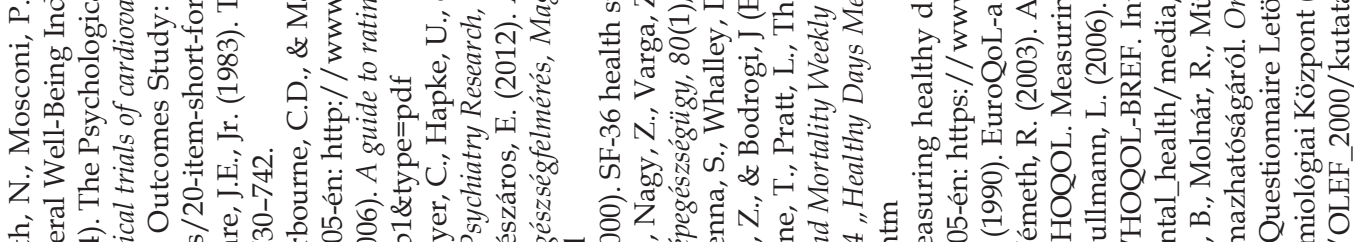

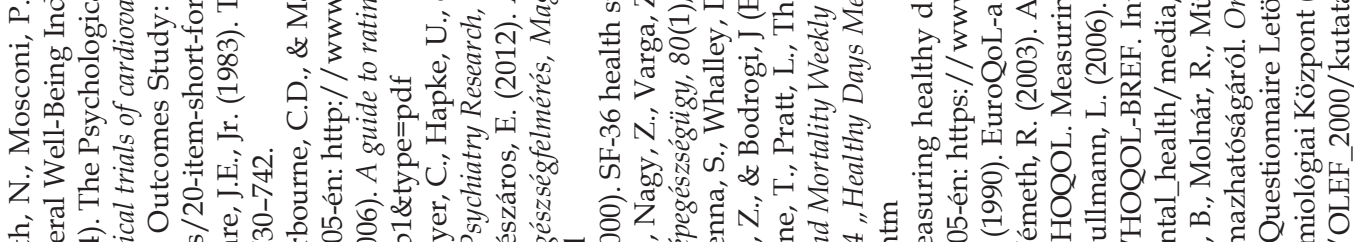

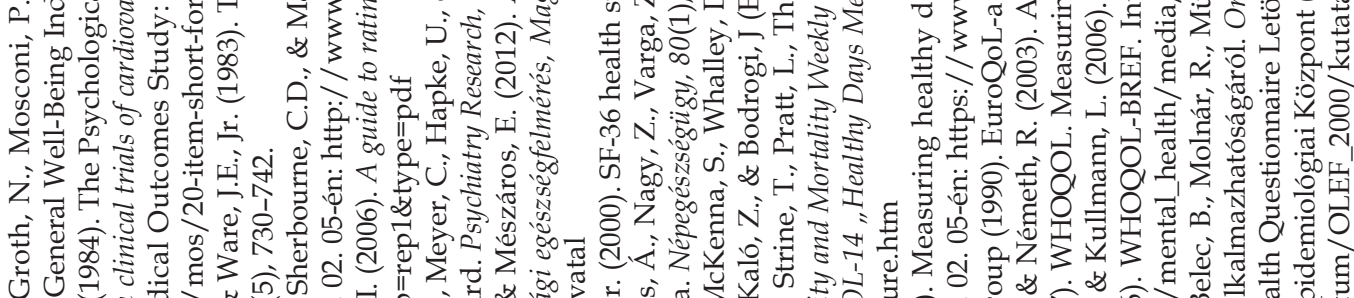

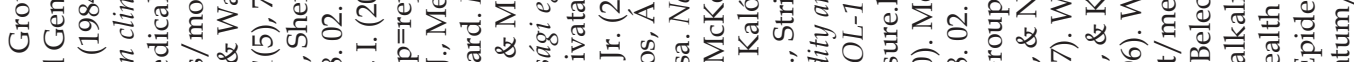

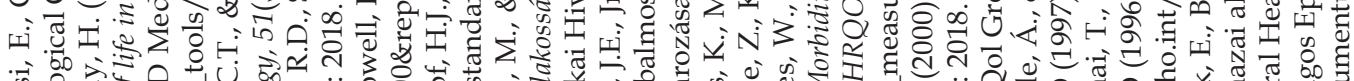
ज.

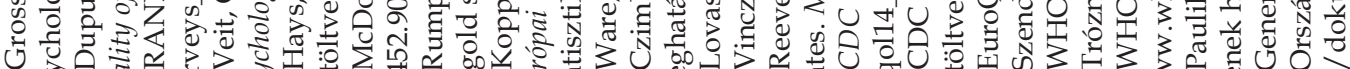
U

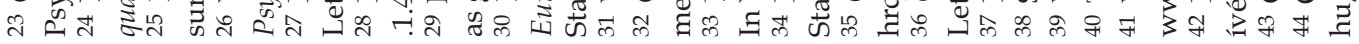




\subsection{A mentális egészség és jóllét vizsgálati eszközei}

A mentális egészség iránti nemzetközi érdeklődést több fejlemény is jelentősen megnövelte az 1990-es évektől. 1990-ben indult az Egészségügyi Világszervezet támogatásával a nemzetközi Globális Betegségteher (Global Burden of Disease) vizsgálat, amely az évtized közepére adatokkal támasztotta alá a mentális betegségek kiemelkedő fontosságát. A neuropszichiátriai/mentális betegségek miatt történő korai halálozás nem szerepel az első 10 leggyakoribb haláloki csoport közt sem globálisan, sem a magas jövedelmú országokat tekintve (WHO, 2015b), de az általuk okozott betegségteher és rokkantság okán e kórképek a nemfertőző betegségek vezető betegségcsoportját képezik, mivel a rokkantsággal megélt életévek nagyobb hányadáért felelősek, mint a szív-érrendszeri vagy a daganatos betegségek (Murray \& Lopez, 1994).

Az 1990-1999 közti évtized az agykutatásnak szentelve telt el („Decade of the Brain") (Jones \& Mendell, 1999), amely jelentős új tudományos ismereteket tárt fel az agymúködésről, tovább növelve a mentális egészség iránti érdeklődést (Butcher, 2000). Harmadrészt, az 1990-es évek közepén indult az a jelenleg is zajló követéses vizsgálat, amelynek 1998-ban megjelent első eredményei a gyermekkori traumák élethosszig tartó, és a felnőttkori mentális állapotot alapvetóen befolyásoló szerepére irányították a figyelmet.7

A közgazdaságtanban ugyancsak a 20. század vége felé bontakoztak ki az emberi jólétet a korábbi formális helyett szubsztantív módon megközelítő irányzatok, amelyek új alapokra helyezték az emberi fejlődés fogalmát és mérését (Gébert, 2012; Kopp \& Martos, 2011). (Kopp és Martos [2011] nyomán a formális elméletek konstruktuma magyarul „jólét”-ként, a szubsztantív elméletek fogalma ,jóllét"-ként fordítandó.)

7 Adverse Childhood Experiences. Centers for Disease Control and Prevention. Letöltve: 2018.02.05én: https://www.cdc.gov/violenceprevention/acestudy/index.html 
A mentális egészség iránti tudományos érdeklődést tükrözi a témában megjelent közlemények száma is, amely a PubMed-en „mental health” kulcsszóval végrehajtott keresés szerint 1980-tól 2016-ig 1277-ről 25036-ra, vagyis közel 20-szorosára nőtt. ${ }^{8}$ Nem véletlen, hogy a mentális egészség iránti fokozódó nemzetközi érdeklődés kapcsán a 20. század utolsó évtizedében bontakozott ki a pszichológiában is az egészséges lelki múködésekkel foglalkozó irányzat, amely hedonikus vagy pozitív pszichológia néven vált ismertté (Kahneman, Diener, \& Schwarz, 1999; Seligman, 1998). Ez az irányzat nem a patológiás, hanem a harmonikus lelkiállapotok vizsgálatát túzi ki célul, s ennek megfelelően más konstruktumokra összpontosítva, a korábbiakban alkalmazottakhoz képest más, a mentális egészség és szubjektív jóllét mérésére alkalmas eszközökre van szüksége. A populációs vizsgálatra alkalmas eszközök jelentős része a Hadley Cantril amerikai pszichológus által az 1960-as években kidolgozott Cantril-létra, illetve a fentebb ismertetett Medical Outcomes Study eszközeinek módosításán alapul. Ezen eszközöket a 4. táblázat tekinti át.

8 Letöltve: 2018.02.05-én: https://www.ncbi.nlm.nih.gov/pubmed/ 


\begin{tabular}{|c|c|c|c|c|c|c|c|c|c|c|}
\hline 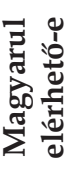 & & $\underset{0}{\mathscr{D}}$ & 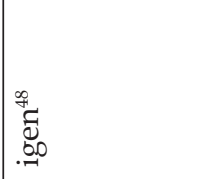 & $\underset{.0}{\widetilde{D}}$ & 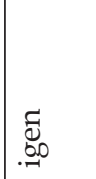 & 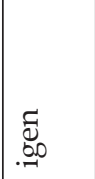 & 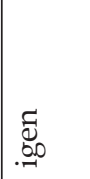 & Ðే. & 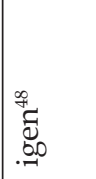 & ॄ્વ \\
\hline 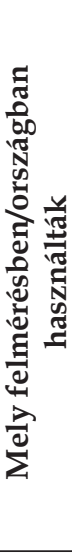 & & 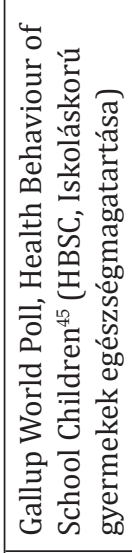 & 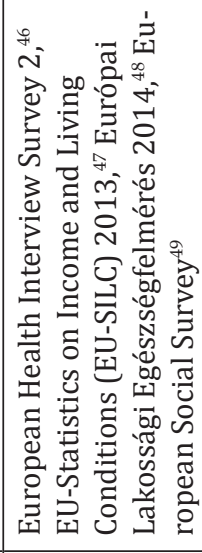 & 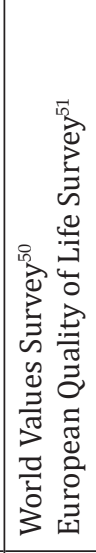 & 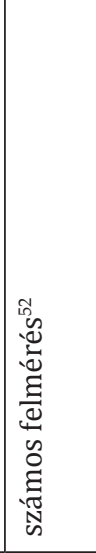 & 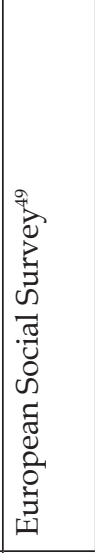 & 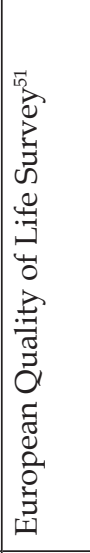 & 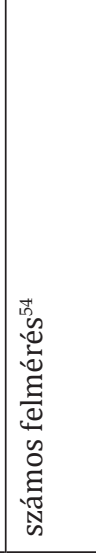 & 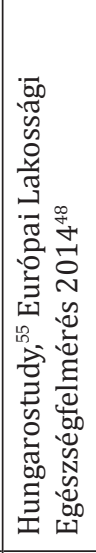 & 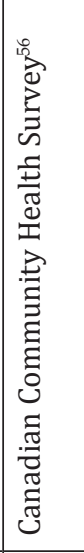 \\
\hline 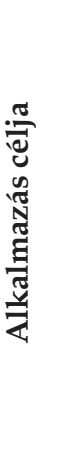 & & 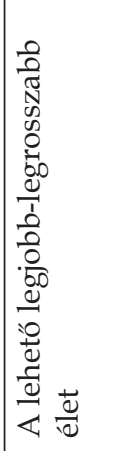 & 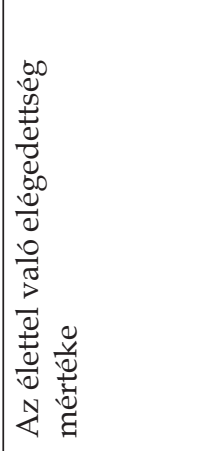 & 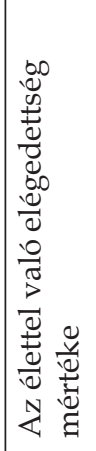 & 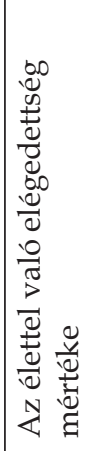 & 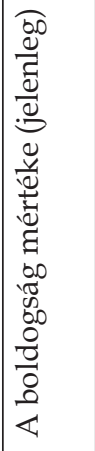 & 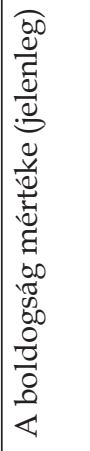 & 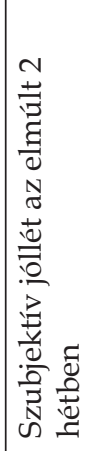 & 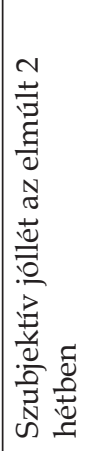 & 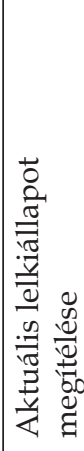 \\
\hline 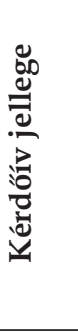 & 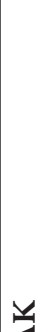 & 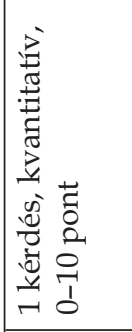 & 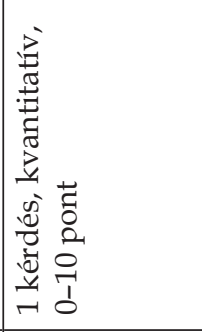 & 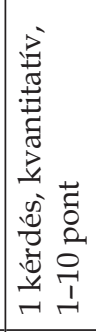 & 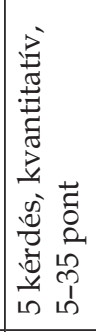 & 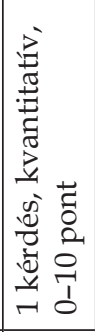 & 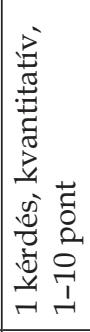 & 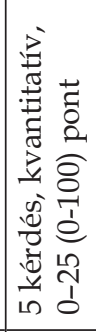 & 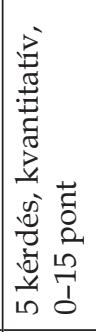 & 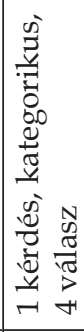 \\
\hline 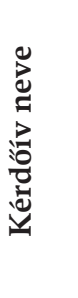 & 这 & 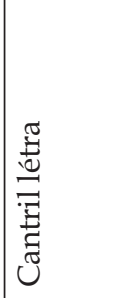 & 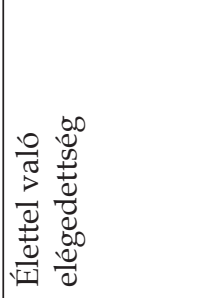 & 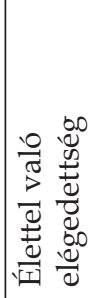 & 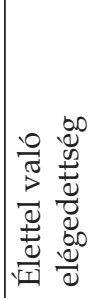 & $\begin{array}{l}0 \\
0 \\
0 \\
0 \\
0 \\
0 \\
0 \\
0 \\
0 \\
0 \\
\infty\end{array}$ & $\begin{array}{l}00 \\
0 \\
0 \\
0 \\
0 \\
0 \\
0 \\
0 \\
0 \\
0\end{array}$ & 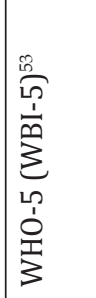 & 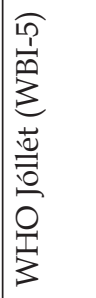 & 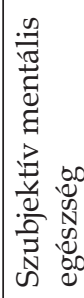 \\
\hline
\end{tabular}




\begin{tabular}{|c|c|c|c|c|c|c|c|c|}
\hline & 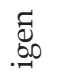 & $\begin{array}{l}\widetilde{D} \\
.0 \\
.0\end{array}$ & . & $\underset{\overparen{D}}{.00}$ & 芯 & & 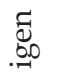 & 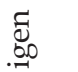 \\
\hline & 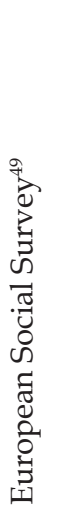 & 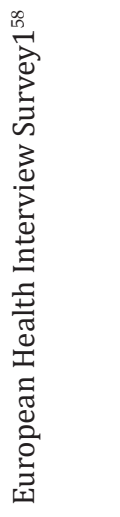 & 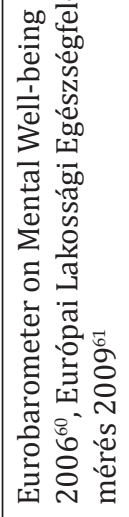 & 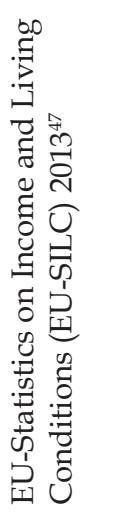 & 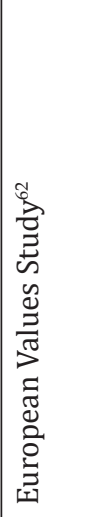 & & 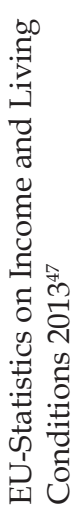 & 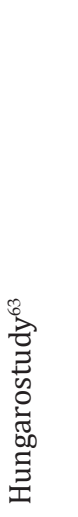 \\
\hline & 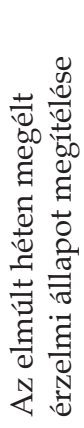 & 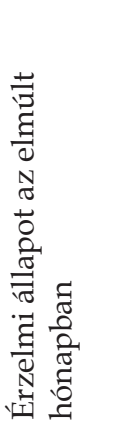 & 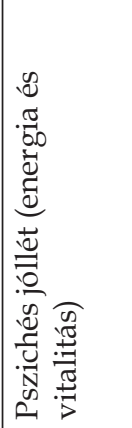 & 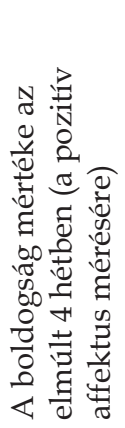 & 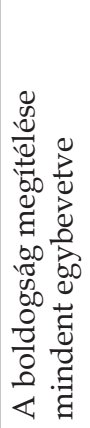 & & 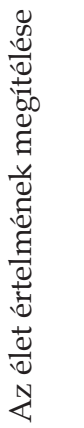 & 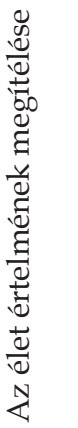 \\
\hline & 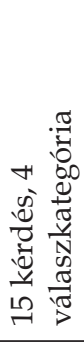 & 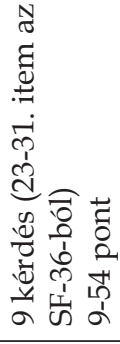 & 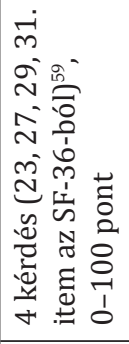 & 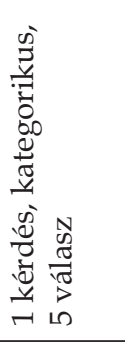 & 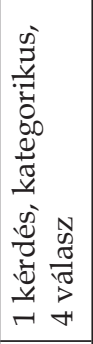 & 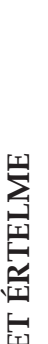 & 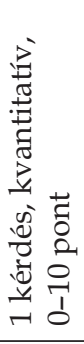 & 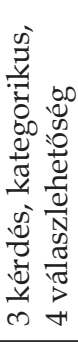 \\
\hline 点 & 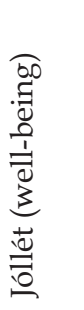 & 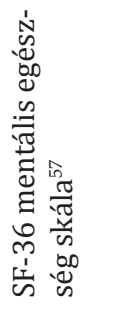 & 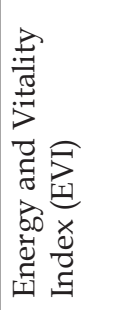 & $\begin{array}{l}00 \\
\tilde{0} \\
0 \\
0 \\
0 \\
0 \\
0 \\
0 \\
0 \\
\infty\end{array}$ & $\begin{array}{l}00 \\
\mathbb{0} \\
0 \\
0 \\
0 \\
0 \\
0 \\
0 \\
0 \\
0\end{array}$ & 雳 & 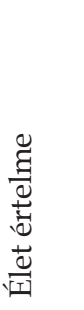 & 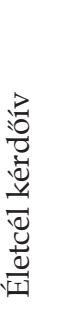 \\
\hline
\end{tabular}

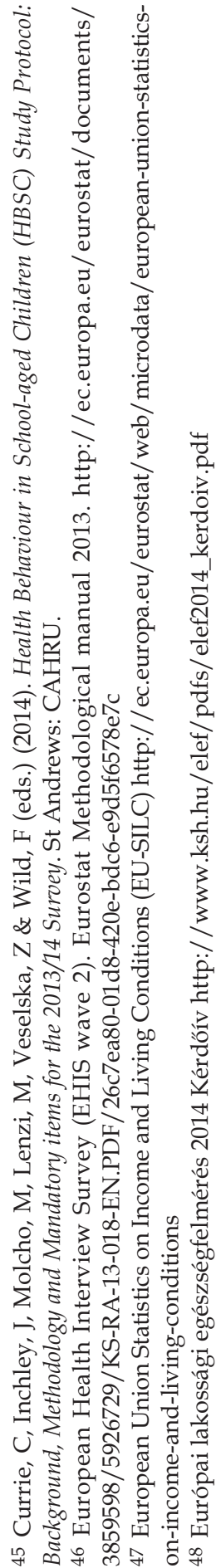




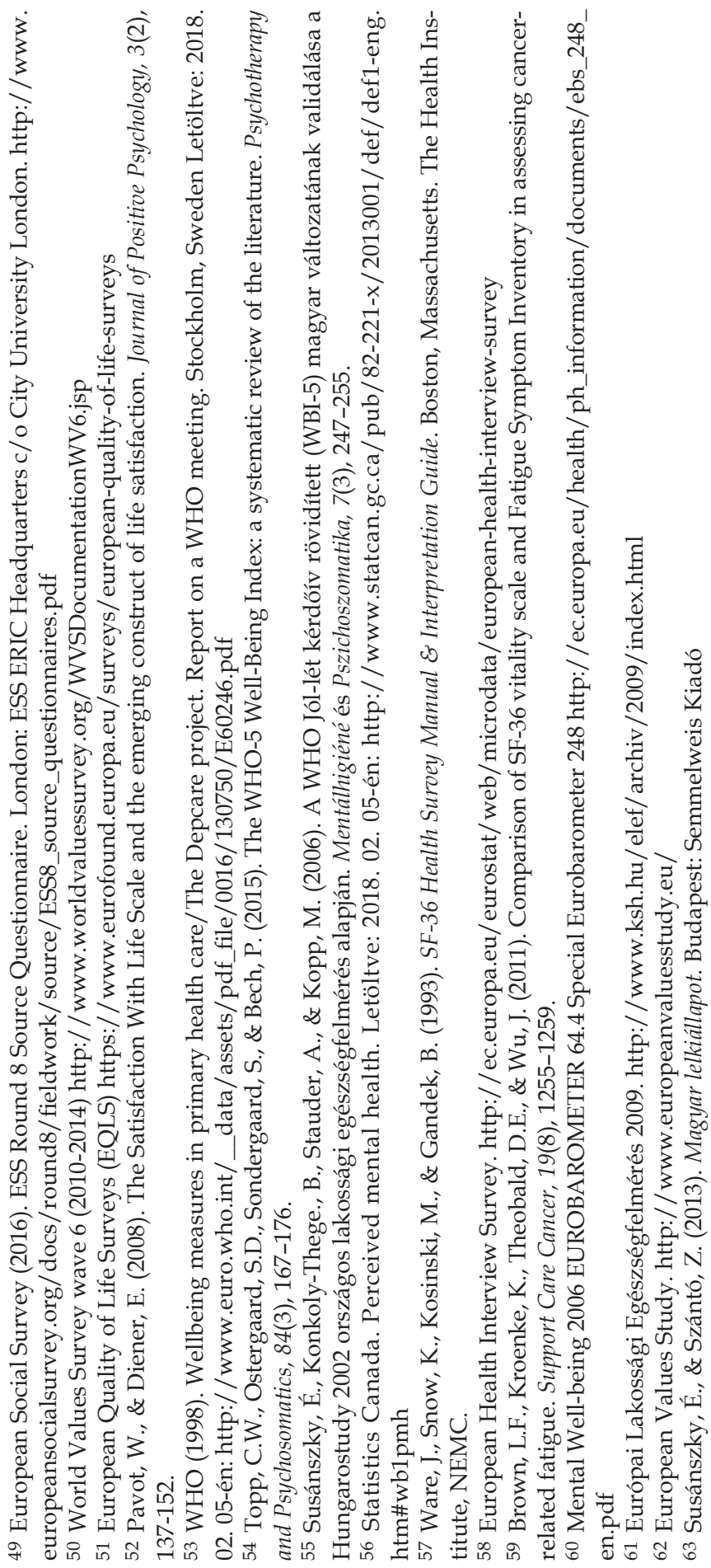




\section{Következtetések}

A rendelkezésre álló adatokból az állapítható meg, hogy a hazai népesség mentális állapota nemzetközi összehasonlításban kedvezőtlen. Magyarország lelki egészség tekintetében évek óta mint az OECD országok sereghajtója, 38 ország közül a negyedik legalacsonyabb pontátlagú ország szerepel, az élettel való elégedettségre vonatkozó egyetlen kérdés alapján. ${ }^{9}$

Hazánkban a szándékos önsértés okozta halálozás a 65 éven aluliak körében a 4. legmagasabb (Eurostat, 2017b) a mentális és viselkedészavarok okozta halálozás ugyanezen korosztályban a 7. legmagasabb volt az EUtagállamok közt 2014-ben (Eurostat, 2017a).

Nem lehet azonban egyértelmú választ adni arra a kérdésre, hogy a hazai népesség mentális állapota hogyan változott az elmúlt években. A Hungarostudy felmérések eredményei szerint a depresszió szempontjából magas kockázatúak (közepes és súlyos depressziós tünetekkel bírók) aránya az 1988-ban mért 7,5\%-ról 2013-ban több mint kétszeresére, 16,7\%-re emelkedett (Susánszky \& Szántó, 2013).

Ugyanakkor a Global Health Data Exchange szerint a depresszív zavarok prevalenciája 1990-ben mindkét nemben, minden korosztályban 3,94\% (95\% megbízhatósági tartomány: 3,66\%-4,25\%) volt, ami 2015-re 3,78\%-ra (95\% megbízhatósági tartomány: 3,53\%-4,05\%) csökkent (IHME, 2018).

Ez utóbbi forrás (a Global Burden of Disease Project háttérintézménye) azonban becsléseihez olyan hazai közleményeket használt - az évente megjelenő kábítószer-jelentésekben található drogfogyasztási adatokat leszámítva -, amelyek közül a legfrissebb 2010-ben jelent meg (IHME, 2016).

Megbízható, idősoros, többféle mutatót standard módszertannal produkáló, reprezentatív adatok volnának szükségesek ahhoz, hogy a mentális zavarokban szenvedő, egészségügyi ellátást igénylő, valamint a mentális problémákkal küzdő, de a betegellátó rendszeren kívül is segíthető populációs alcsoportok problémáit, létszámát, demográfiai jellemzőit meg lehessen határozni. Ilyen adatok nélkül nem lehet bizonyítékokon alapuló konkrét beavatkozásokat tervezni, sem azok költségeit meghatározni. Erre a hiányra a WHO-nak a hazai mentális egészségügyi ellátást értékelő csoportja is felhívta a figyelmet (Bitter, Kurimay, Silling, \& Harangozó, 2014). Ez - a mentális egészség és mentális zavarok egy halmazban való kezelése mellett szintén hozzájárul ahhoz, hogy a lelki egészségre vonatkozóan máig nem sikerült kormányzati konceptuális és financiális támogatással bíró hazai

\footnotetext{
9 Better life index. Letöltve: 2018. 02. 05-én: http:/ / www.oecdbetterlifeindex.org/\#/00000000500
} 
cselekvési tervet elfogadtatni, sem önállóan, sem egészségügyi vagy népegészségügyi tervbe ágyazottan. ${ }^{10}$

Reményt keltő ugyanakkor, hogy az egyik legfontosabb hazai szakmai múhely, a Semmelweis Egyetem Pszichiátriai és Pszichoterápiás Klinika tagja volt annak a közelmúltban zárult európai projektnek (ROAMER), amely meghatározta a mentális egészség kutatásának európai prioritásait (Wykes és mtsai, 2015), és amely remélhetőleg a közeljövőben elérhetóvé teszi a mentális zavarok populációs vizsgálata szempontjából legmegbízhatóbb eszköz (CIDI) magyar nyelvú változatát. Az EU mentális egészségre és jóllétre vonatkozó közös akciótervének (Joint Action on Mental Health and Well-Being) 5 prioritási témája közül a depresszió és öngyilkosság megelőzését célzó munkacsomagot is hazai szakemberek, a Semmelweis Egyetem szakemberei vezették ${ }^{11}$ (Coppens és mtsai, 2018).

A mentális egészség és mentális betegségek/zavarok populációs vizsgálata szempontjából kulcsfontosságú a vizsgálattervezés és a módszertan, amelynek kidolgozásába az esetdefiníciótól a vizsgálati eszközökön és a mintaválasztáson keresztül az adatgyújtés és elemzés részletei is beletartoznak. Ezek a részletek biztosítják, hogy olyan adatokat lehessen elóállítani, amelyek a tudományos kutatás és nemzetközi összehasonlítás elvárásainak maradéktalanul megfelelnek. Ehhez kívántak hozzájárulni a szerzők a mentális egészség populációs vizsgálatára vonatkozó legfontosabb szempontok és eszközök áttekintésével.

\section{Irodalom}

Ahmad, F., Jhajj, A.K., Stewart, D.E., Burghardt, M., \& Bierman, A.S. (2014). Single item measures of self-rated mental health: a scoping review. BMC Health Services Research, 14:398. Doi: 10.1186/1472-6963-14-398

Allport, G.W. (1927). Concepts of trait and personality. Psychological Bulletin, 24, 284-293.

APA. (2013). DSM-5 referencia kézikönyv a DSM-5 diagnosztikai kritériumaihoz (Gonda, X., Balázs, J., \& Keresztény, Á., ford.). Budapest: Oriold.

Baxter, A.J., Patton, G., Scott, K.M., Degenhardt, L., \& Whiteford, H.A. (2013). Global epidemiology of mental disorders: what are we missing? PLoS One, 8(6), e65514. Doi: 10.1371/journal.pone.0065514

Bitter, I., Kurimay, T., Silling, T., \& Harangozó, J. (2014). A magyar mentális egészségügyi ellátás értékelése. Vezetôi összefoglaló Budapest: Egészségügyi Világszervezet.

10 Nemzeti Lelki Egészség Stratégia 2014-2020. Szakpolitikai stratégia tervezet 2014. 2014). Letöltve: 2017. 10.01-én: http://www.pef.hu/pef/resources/documents/nemzeti_lelki_egeszseg_ strategia_tervezet_pef_kiegeszitesekkel.pdf

11 Depression, suicide and e-health. Letöltve: 2018. 02. 05-én: http://www.mentalhealthandwell being.eu/depression-suicide-and-e-health\#outcomes 
Breslow, L. (1972). A quantitative approach to the World Health Organization definition of health: physical, mental and social well-being. International Journal of Epidemiology, 1(4), 347-355.

Brook, R.H., Emmett B. Keeler, Lohr, K.N., Newhouse, J.P., Ware, J.E., Rogers, W.H., et al. (2006). The Health Insurance Experiment. Letöltve: 2018. 02. 05-én: https:/ /www.rand. org/pubs/research_briefs/RB9174.html

Buda, B. (1994). Mentálhigiéné. A lelki egészség társadalmi, munkaszervezeti, pszichokulturális és gyakorlati vetületei. Tanulmánygyüjtemény: Animula Egyesület.

Butcher, J. (2000). A Nobel pursuit. Lancet, 356(9238), 1331. Doi: 10.1016/S0140-6736(00) 02825-7

Carter, J. (1977). Executive Order 11973 - President's Commission on Mental Health. Letöltve: 2018.03.07-én: http:/ / www.presidency.ucsb.edu/ws/index.php?pid=6643

Coppens, E., Van Audenhove, C., Gusmao, R., Purebl, G., Szekely, A., Maxwell, M., et al. (2018). Effectiveness of General Practitioner training to improve suicide awareness and knowledge and skills towards depression. Journal of Affective Disorders, 227, 17-23.

Cottler, L.B. (1990). The CIDI and CIDI-substance abuse module (SAM): cross-cultural instruments for assessing DSM-III, DSM-III-R and ICD-10 criteria. NIDA Research Monograph, 105, 220-226.

Davies, A., Sherbourne, C., Peterson, J., \& Ware, J. (1988). Scoring manual: Adult health status and patient satisfaction measures used in RAND's Health Insurance Experiment. Santa Monica: RAND Corporation.

Earl-Slater, A. (1999). Dictionary of Health Economics. Abingdon, Oxon: Radcliffe Medical Press Ltd.

Európai Bizottság (2008). A lelki egészség és jól-lét európai paktuma. Letöltve: 2018. 02. 05-én: https:/ / ec.europa.eu/health//sites/health/files/mental_health/docs/mhpact_hu.pdf

European Commission (2013). Evaluation of the use and impact of the European Community Health Indicators ECHI. Letöltve: 2018. 01. 10-én: https:/ / ec.europa.eu/health/sites/ health/files/indicators/docs/echi_report_v20131031.pdf

European Commisson (2016). European Framework for Action on Mental Health and Wellbeing. Letöltve: 2018. 02. 05-én: http://www.mentalhealthandwellbeing.eu/assets/docs/ publications/Framework\%20for\%20action_19jan\%20(1)-20160119192639.pdf

Eurostat. (2010). EHIS indicators guidelines. List of indicators to be computed with the EHIS. Letöltve: 2018. 02. 05-én: https:/ / circabc.europa.eu/d/d/workspace/SpacesStore/ d4c9d574-8658-4c21-9cf2-04768b38afe8/EHIS\%20indicators \% 20quidelines \% 20-\% 20 final\%20version.pdf

Eurostat (2017a). Causes of death - mental and behavioural disorders, residents. Letöltve: 2018. 02. 05-én: http:/ / ec.europa.eu/eurostat/statistics-explained/index.php/File:Causes_ of_death_\%E2\%80\%94_mental_and_behavioural_disorders,_residents,_2014_HLTH17. png

Eurostat (2017b). Standardised death rates - intentional self-harm, residents, 2014 (per 100000 inhabitants) Letöltve: 2018.03.07-én: http:/ / ec.europa.eu/ eurostat/statistics-explained/ index.php/File:Standardised_death_rates_\%E2\% 80\%94_intentional_self-harm,_ residents,_2014_(per_100_000_inhabitants)_HLTH17.png

Fidy, J., \& Makara, G. (2005). Biostatisztika. Letöltve: 2018. 02. 05-én: http:/ / www.tankonyvtar. $\mathrm{hu} / \mathrm{hu} /$ tartalom/tkt/ biostatisztika-1/ch09s02.html

Forsman, A.K., Ventus, D.B., van der Feltz-Cornelis, C.M., \& Wahlbeck, K. (2014). Public mental health research in Europe: a systematic mapping for the ROAMER project. European Journal of Public Health, 24(6), 955-960. 
Gébert, J. (2012). A jólét mérésének elméleti alapjai és problémái. In Bajmócy, Z., Lengyel, I., \& Málovics, G. (Szerk.), Regionális innovációs képesség, versenyképesség és fenntarthatóság. Szeged: JATEPress.

Hays, R.D., Sherbourne, C.D., \& Mazel, R.M. (Ed.) (1995). User's manual for the Medical Outcomes Study (MOS) core measures of health-related quality of life: RAND. Letöltve: 2018. 02. 05-én: https://www.rand.org/pubs/monograph_reports/MR162.html

Hunt, S.M., McEwen, J., \& McKenna, S.P. (1985). Measuring health status: a new tool for clinicians and epidemiologists. The Journal of the Royal College of General Practitioners, 35(273), 185-188.

IHME. (2016). Global Burden of Disease Study 2016 (GBD 2016). Data Input Sources Tool. Letöltve: 2018. 02. 05-én: http://ghdx.healthdata.org/gbd-2016/data-input-sources?loca tions $=48 \&$ components $=5 \&$ causes $=558$

IHME. (2018). Global Health Data Exchange. Letöltve: 2018. 02. 05-én: http:/ / ghdx.healthdata. org/gbd-results-tool

Jahoda, M. (1958). Current concepts of positive mental health. New York: Basic Books

Jones, E.G., \& Mendell, L.M. (1999). Assessing the decade of the brain. Science, 284(5415), 739.

Kahneman, D., Diener, E., \& Schwarz, N. (1999). Well-being: the foundations of hedonic psychology. New York: Russell Sage Foundation

Kessler, R.C., Petukhova, M., \& Zaslavsky, A.M. (2011). The role of latent internalizing and externalizing predispositions in accounting for the development of comorbidity among common mental disorders. Current Opinion in Psychiatry, 24(4), 307-312.

Kopp, M., \& Martos, T. (2011). A magyarországi gazdasági növekedés és társadalmi jóllét, életminőség viszonya. Letöltve: 2018. 02. 05-én: http://ess.tk.mta.hu/wp-content/ uploads/2013/04/kopp_gazdasagi_novekedes.pdf

Krueger, R.F., Caspi, A., Moffitt, T.E., \& Silva, P.A. (1998). The structure and stability of common mental disorders (DSM-III-R): a longitudinal-epidemiological study. Journal of Abnormal Psychology, 107(2), 216-227.

Manwell, L.A., Barbic, S.P., Roberts, K., Durisko, Z., Lee, C., Ware, E., et al. (2015). What is mental health? Evidence towards a new definition from a mixed methods multidisciplinary international survey. BMJ Open, 5(6), e007079. Doi: 10.1136/bmjopen-2014-007079

Murray, C.J., \& Lopez, A.D. (1994). Quantifying disability: data, methods and results. Bulletin of the World Health Organization, 72(3), 481-494.

NIMH. (2017). What is prevalence? Letöltve: 2018. 02. 05-én: https://www.nimh.nih.gov/ health/statistics/what-is-prevalence.shtml

NM GYÓGYINFOK (Szerk.). (1995). BNO-10: A betegségek és az egészséggel kapcsolatos problémák nemzetközi statisztikai osztályozása. Budapest: Népjóléti Minisztérium

Perczel-Forintos, D., Ajtay, G., Barna, C., Kiss, Z., \& Komlósi, S. (2012). Kérdőívek, becslőskálák a klinikai pszichológiában. Budapest: Semmelweis Kiadó

Plomin, R., DeFries, J.C., \& Fulker, D.W. (1988). Nature and nurture during infancy and early childhood. Cambridge; New York: Cambridge University Press.

Rai, D., Zitko, P., Jones, K., Lynch, J., \& Araya, R. (2013). Country- and individual-level socioeconomic determinants of depression: multilevel cross-national comparison. The British Journal of Psychiatry, 202(3), 195-203.

Robins, L.N., Helzer, J.E., Croughan, J., \& Ratcliff, K.S. (1981). National Institute of Mental Health Diagnostic Interview Schedule. Its history, characteristics, and validity. Archives of General Psychiatry, 38(4), 381-389. 
Robins, L.N., Wing, J., Wittchen, H.U., Helzer, J.E., Babor, T.F., Burke, J., et al. (1988). The Composite International Diagnostic Interview. An epidemiologic Instrument suitable for use in conjunction with different diagnostic systems and in different cultures. Archives of General Psychiatry, 45(12), 1069-1077.

Rumpf, H.J., Meyer, C., Hapke, U., \& John, U. (2001). Screening for mental health: validity of the MHI-5 using DSM-IV Axis I psychiatric disorders as gold standard. Psychiatry Research, 105(3), 243-253.

Seligman, M. (1998). The president's address. Letöltve: 2018. 02. 05-én: https:/ / ppc.sas.upenn. edu/sites/ppc.sas.upenn.edu/files/APA\%20President\%20Address\%201998.docx

Steel, Z., Marnane, C., Iranpour, C., Chey, T., Jackson, J.W., Patel, V., et al. (2014). The global prevalence of common mental disorders: a systematic review and meta-analysis 19802013. International Journal of Epidemiology, 43(2), 476-493.

Susánszky, É., \& Szántó, Z. (2013). Magyar lelkiállapot. Budapest: Semmelweis Kiadó

Szádóczky, E., Fazekas, I., Füredi, J., \& Papp, Z. (1996). Kedélybetegségek és szorongásos zavarok előfordulása a családorvosi gyakorlatban: A Diagnostic Interview Schedule (DIS) magyar változatának alkalmazásával. Psychiatria Hungarica, 11(5), 495-503.

Szádóczky, E., Rihmer, Z., Papp, Z., \& Füredi, J. (1997). The prevalence of affective and anxiety disorders in primary care practice in Hungary. Journal of Affective Disorders, 43(3), 239-244.

Tarlov, A.R., Ware, J.E., Jr., Greenfield, S., Nelson, E.C., Perrin, E., \& Zubkoff, M. (1989). The Medical Outcomes Study. An application of methods for monitoring the results of medical care. JAMA, 262(7), 925-930.

van den Beukel, T.O., Siegert, C.E., van Dijk, S., Ter Wee, P.M., Dekker, F.W., \& Honig, A. (2012). Comparison of the SF-36 Five-item Mental Health Inventory and Beck Depression Inventory for the screening of depressive symptoms in chronic dialysis patients. Nephrology, dialysis, transplantation, 27(12), 4453-4457.

Veit, C.T., \& Ware, J.E., Jr. (1983). The structure of psychological distress and well-being in general populations. Journal of Consulting and Clinical Psychology, 51(5), 730-742.

Vollebergh, W.A., Iedema, J., Bijl, R.V., de Graaf, R., Smit, F., \& Ormel, J. (2001). The structure and stability of common mental disorders: the NEMESIS study. Archives of General Psychiatry, 58(6), 597-603.

Ware, J., Snow, K., Kosinski, M., \& Gandek, B. (1993). SF-36 Health Survey Manual E Interpretation Guide. Boston, Massachusetts The Health Institute, NEMC.

Ware, J.E., Jr. (2000). SF-36 health survey update. Spine (Phila Pa 1976), 25(24), 3130-3139.

WHO (1946). Preamble to the Constitution of the World Health Organization Official records of the World Health Organization No 2. Summary report on proceedings minutes and final acts of the International Health Conference (pp. 16-27): World Health Organization. Letöltve: 2018. 02. 05-én: http:/ / apps.who.int/iris/bitstream/10665/85573/1/Official_record2_ eng.pdf

WHO (2001). World Health Report 2001 - Mental health: new understanding, new hope. Letöltve: 2018. 02. 05-én: http://www.who.int/whr/2001/en/

WHO (2003). Investing in mental health. Letöltve: 2018. 02. 05-én: http:/ /www.who.int/ mental_health/media/investing_mnh.pdf

$\mathrm{WHO}$ (2008). Closing the gap in a generation: Health equity through action on the social determinants of health. Final report. WHO, Commission on Social Determinants of Health. Letöltve: 2018. 02. 06-án: http://apps.who.int/iris/bitstream/10665/43943/1/9789241563703_ eng.pdf

WHO (2013a). Investing in mental health: evidence for action. Letöltve: 2018. 02. 05-én: http:/ / apps.who.int/iris/bitstream/10665/87232/1/9789241564618_eng.pdf?ua=1 
WHO (2013b). Mental health action plan. 2013-2020. Letöltve: 2018. 02. 05-én: http:/ /apps. who.int/iris/bitstream/10665/89966/1/9789241506021_eng.pdf?ua=1

WHO (2015a). The European Mental Health Action Plan 2013-2020 Letöltve: 2018. 02. 05-én: http:/ / www.euro.who.int/_data/assets/pdf_file/0020/280604/WHO-EuropeMental-Health-Acion-Plan-2013-2020.pdf

WHO. (2015b). The top 10 causes of death. Letöltve: 2018.03.07-én: http:/ /www.who.int/ mediacentre/factsheets/fs310/en/index1.html

Wykes, T., Haro, J.M., Belli, S.R., Obradors-Tarrago, C., Arango, C., Ayuso-Mateos, J.L., et al. (2015). Mental health research priorities for Europe. Lancet Psychiatry, 2(11), 1036-1042. Yin, S., Njai, R., Barker, L., Siegel, P.Z., \& Liao, Y. (2016). Summarizing health-related quality of life (HRQOL): development and testing of a one-factor model. Population Health Metrics, 14:22. Doi: 10.1186/s12963-016-0091-3

\title{
Köszönetnyilvánítás
}

A szerzók köszönetet mondanak Somogyi Gergőnek az ábrák elkészítéséért. A tanulmány elkészítését a GINOP-2.3.2-15-2016-00005 számú projekt támogatta. A projekt az Európai Unió támogatásával, az Európai Regionális Fejlesztési Alap társfinanszírozásával valósult meg.

\section{A szerzók munkamegosztása}

Kósa Karolina: a cikk koncepciójának kidolgozása, szakirodalmi keresés, a kézirat megszövegezése és a végleges szöveg elkészítése. Bíró Éva: szakirodalmi keresés, közremúködés a kézirat megszövegezésében, a végleges szöveg ellenőrzése.

\section{Nyilatkozat érdekütközésról}

A szerzők kijelentik, hogy esetükben nem állnak fenn érdekütközések.

\section{Concepts and tools of population mental health surveys}

\author{
KÓSA, KAROLINA - BÍRÓ, ÉVA
}

There has been a growing international interest in population mental health, attested to by the large number of scientific research studies and international documents dedicated to this topic in the past three decades. However, interest in and dedication to this field has not been reflected by the number of studies that would provide population estimates enabling international comparison, based on well designed and carefully implemented studies. Reliable studies of mental health conducted in the Hungarian population that are also appropriate for international comparisons have been also lacking thereby hindering the development and acceptance of a well targeted and evidence-based national mental health strategy. The authors wish to contribute to the development of the national mental 
health strategy by presenting major conceptual and methodological dilemmas arising when representative mental health surveys are designed. The most frequently used tools to measure mental disorders, generic mental status and mental health at the population level are also summarized. The mental status of the Hungarian population should be regularly monitored using internationally comparable methodology so as not only to produce valid data for the development of a strategy to improve mental health but also to enable the follow-up of the effectiveness of policy interventions.

Keywords: mental health, epidemiology, questionnaire surveys 